\title{
LA PROBLEMÁTICA FORESTAL EN LA PROVINCIA DEL CHACO, ARGENTINA. UN ANÁLISIS DESDE LA GEOGRAFÍA
}

\section{THE FORESTRY ISSUES IN THE PROVINCE OF CHACO, ARGENTINA. AN ANALYSIS FROM GEOGRAPHY}

\author{
Dr. Dante Edin Cuadra \\ Profesor Adjunto e Investigador del Departamento de Geografía. Facultad de Humanidades, UNNE. \\ Director del Instituto de Geografía de la Universidad Nacional del Nordeste, Argentina. \\ dantecuadra@yahoo.com
}

\section{Resumen}

El bosque chaqueño se ha constituido, actualmente, en una problemática en la que se hallan involucrados diferentes actores y sectores de la sociedad, muchas veces opuestos en sus intereses, que convergen en un escenario de conflictos que se reflejan recurrentemente, tanto en los medios periodísticos como en las agendas políticas y en los estrados judiciales. Sucede que en la corta historia del Chaco, al bosque se le asignaron conceptualizaciones, valoraciones y status muy diferentes, como son los de hábitat, obstáculo natural, recurso geoestratégico, recurso natural y variable de ajuste del sistema agropecuario, hasta llegar hoy a una yuxtaposición de estos roles y atributos, según la óptica e intereses de cada actor o sector participante. Por ello y, como contexto de un proyecto de investigación que se encuentra en su fase inicial, denominado "La actividad forestal en el Chaco y los sectores conexos. Efectos socioeconómicos y ambientales a través del tiempo", se ha procedido a analizar la bibliografía disponible sobre el tema e iniciar un ejercicio de reflexión acerca de los modos con que los grupos humanos se han relacionado con el bosque en el transcurso del tiempo y, particularmente, en el presente. De esta manera, se pretende echar un poco de luz sobre el origen y los procesos que han llevado a los bosques del Chaco a ocupar en nuestros días un protagonismo inusual y, a la vez, constituirse en una preocupación central dentro de la sociedad chaqueña, que convoca a productores madereros y agropecuarios, transportistas, organismos del Estado, gremios, comunidades originarias, organizaciones no gubernamentales y de derechos humanos, ambientalistas, juristas y geógrafos, entre otros. Si bien ha habido avances en el campo legislativo, lamentablemente, al no producirse los consensos que resuelvan los conflictos planteados y en tanto los actores políticos no sean capaces de generar las acciones adecuadas en materia socioambiental, el empobrecido bosque chaqueño continuará su curso de degradación, sumándose a las áreas deforestadas o de gran impacto, donde los daños ambientales, sociales, económicos y culturales son ya irreversibles.

Palabras claves: Bosque; Valorizaciones; Sociedad; Ambiente; Degradación.

\section{Summary}

The forest of Chaco has become, currently, a problem which involves different actors and sectors of society, often opposed in their interests, which converge in a scenario of recurring conflicts that are reflected both in the media as on political agenda and in tribunals. It happens that in the short history of Chaco, the forest was given different conceptualizations, appraisals and status, such as habitat, natural obstacle, geostrategic resource, natural resource and adjustment variable of the agricultural system, up to a juxtaposition today of these roles and attributes, according to the point of view and interests of each actor or participating sector. Therefore, in the context of a research project in its initial phase, called "Forestry in Chaco and related sectors. Socioeconomic and environmental effects over time", we proceeded to analyze the available literature on the subject and start a reflection exercise on the ways in which human groups have been linked to the forest over time and particularly in the present. In this way, we want to shed some light on the origin and the processes that led the forests of Chaco to gain an unusual prominence and, at the same time, become a central concern in the society of Chaco, in which converge timber and agricultural producers, shippers, government agencies, unions, indigenous communities, NGOs and human rights organizations, environmentalists, 
jurists and geographers, among others. While there has been progress in the legislative field, as long as the lack of consensus to resolve the conflicts arisen remain, and political actors are not capable of generating appropriate action on socio-environmental matter, the impoverished Chaco forest will continue its course of degradation, adding to the deforested or high-impact areas, where environmental, social, economic and cultural damage is already irreversible.

Keywords: Forest; Appraisals; Society; Environment; Degradation.

\title{
SUMARIO
}

\author{
Introducción. \\ Objetivos. \\ Materiales y métodos. \\ Resultados. \\ El bosque chaqueño como hábitat de pueblos originarios. \\ El bosque chaqueño como obstáculo natural de la conquista territorial. \\ El bosque chaqueño como recurso natural. \\ El bosque chaqueño como recurso geoestratégico. \\ El bosque chaqueño como variable de ajuste del sistema agropecuario. \\ La nueva Ley de Bosques. \\ Múltiples intereses y alta conflictividad. \\ Los problemas del uso sustentable. \\ Las dicotomías legales y el problema de la ilegalidad. \\ La actividad forestal: un sistema deficiente. \\ Las actividades conexas. \\ Consideraciones finales. \\ Fuentes y bibliografía consultadas.
}

\section{Introducción}

El bosque chaqueño es, claramente, objeto de estudio de la Geografía, más allá de que en la literatura disciplinar no aparezca con demasiada frecuencia la rama Geografía Forestal dentro del campo de la Geografía Humana, habiéndoselo estudiado tradicionalmente como una de las diversas formaciones fitogeográficas, dentro de la Biogeografía o de la Fisiografía. Estas ramas abordan el estudio del bosque como entidad natural, morfo-estructural o biosistémica y las relaciones que sostiene con los demás elementos de la naturaleza (relieves, climas, suelos, aguas) y, excepcionalmente, incluyen algunos temas que suelen denominarse Biogeografía Cultural, en los que se tratan algunas modificaciones introducidas o recreaciones producidas por el hombre (incorporación o reemplazo de especies, creación de reservas o áreas protegidas, implantación de bosques, plazas arboladas, etc.). Pero, donde el elemento o hecho espacial llamado "bosque" cobra real dimensión como objeto de estudio de la Geografía es en su abordaje centrado en la relación hombre-medio y, mejor aún, cuando constituye parte indisoluble de una construcción socio-histórica, como puede observarse en el espacio geográfico del Chaco.

En el enfoque geográfico denominado "de la percepción y el comportamiento" hemos aprendido que el medio real nos brinda información, la cual es incorporada a nuestros cerebros por medio de los sentidos $y$, de ese modo, obtenemos o generamos una imagen de esa realidad; pero, en el proceso, la información debe pasar por una serie de filtros (valores, conocimientos, cultura a la que pertenecemos), que pueden jugarnos a favor o en contra en cuanto al ajuste o distorsión de la imagen resultante. Esta perspectiva también sostiene que la imagen puede corregirse al cotejarse con el medio real. De una u otra manera, la imagen o mapa mental que se haya formado cada individuo influirá decisivamente en el tipo de decisiones que tomará y en las acciones que emprenderá sobre ese medio concreto donde vive, trabaja o gobierna.

La "geografía humanista" también llegó a conclusiones próximas, sobre todo a partir de los aportes conceptuales de Yi-Fu Tuan, quien nos habla del "lugar", no como un simple escenario o continente de la vida humana, sino un espacio cargado de simbolismos, valoraciones, sentimientos y, por qué no, fantasías y creencias (subjetividades e inmaterialidades), es decir, un espacio vivencial, donde los hombres y sociedades desarrollan raíces emotivas, a las que sintetizamos con la palabra

Publicado en formato digital: Dr. Dante Edin Cuadra. LA PROBLEMÁTICA FORESTAL EN LA PROVINCIA DEL CHACO, ARGENTINA. UN ANÁLISIS DESDE LA GEOGRAFÍA. Revista Geográfica Digital. IGUNNE. Facultad de Humanidades. UNNE. Año 9. No 18. Julio - Diciembre 2012. ISSN 1668-5180 Resistencia, Chaco. En: http://hum.unne.edu.ar/revistas/geoweb/default.htm 
"arraigo". En esta línea, el mencionado autor nos ha brindado, entre otros, los conceptos de "topofilia" (amor, identificación con el lugar), "topolatría" (adoración, unión espiritual con el lugar) y "topofobia" (rechazo, desagrado, miedo, desconfianza o disconformismo con el espacio geográfico donde vive o le toca interactuar). Como es de imaginar, la actitud y el comportamiento de los hombres para con su entorno, en cada una de estas situaciones, serán muy diferentes.

La "geografía cultural posmoderna" contribuye aún más en esta concepción, al definir al espacio geográfico como una construcción socio-cultural en el que juegan un papel primordial los elementos y las relaciones inmateriales, tanto en su interpretación como en su recreación. Aquello que conocemos como legado cultural, idiosincrasia, discursividad, caracteres identitarios, códigos sociales o cosmovisión de un pueblo o grupo humano, se forjan dentro de ese proceso constructivo.

Las percepciones y, en definitiva, las concepciones que los grupos humanos tienen de los espacios geográficos son construcciones psicológicas, socio-históricas y culturales. Por tanto, es esperable que quienes han habitado desde siempre un lugar no coincidan con muchas apreciaciones, valoraciones y actitudes de inmigrantes recientes o personas que se hallen de paso, como trabajadores estacionales (golondrinas), grupos relocalizados o militares que cumplen funciones durante algunos años y luego son trasladados. Sus cosmovisiones (visión del mundo desde su propia cultura) diferirán entre unos y otros y, por tanto, también sus decisiones y acciones sobre el espacio geográfico.

El Chaco, al tener una historia institucional muy reciente -iniciada a fines del siglo XIX- en la que, con suerte, han transcurrido sólo cinco generaciones, ha experimentado profundamente estos procesos de visiones diferentes, crisis de identidad y conflictos no resueltos o mal resueltos que, consiguientemente, desencadenaron un cúmulo de efectos negativos que afectaron tanto a grupos humanos como al medio natural, al tiempo que ciertos sujetos y sectores obtenían considerables beneficios.

\section{Objetivos}

-Analizar la relación entre los grupos humanos y el bosque en el territorio chaqueño, como producto de diferentes valoraciones a lo largo de su proceso histórico.

-Reconocer los factores materiales y simbólicos que actuaron en detrimento de la riqueza forestal en el Chaco.

-Identificar los actores y sectores que cumplieron y cumplen roles relevantes en la dinámica evidenciada por el bosque nativo chaqueño.

\section{Materiales y métodos}

Este trabajo se encuadra en un proyecto de investigación titulado "La actividad forestal en el Chaco y los sectores conexos. Efectos socioeconómicos y ambientales a través del tiempo", que lleva adelante un equipo de geógrafos de la UNNE. Para esta publicación, las tareas consistieron en:

a) Búsqueda de datos: consultas de fuentes y datos provenientes de organismos gubernamentales y no gubernamentales. Entrevistas con funcionarios, productores agropecuarios, emprendedores foresto-industriales y representantes de organizaciones civiles. Recopilación de fotografías, material cartográfico e imágenes satelitales. Producción fotográfica propia in situ.

b) Sistematización de la información, de acuerdo con los objetivos previstos.

c) Revisión crítica de la información proveniente de documentos primarios y secundarios, elaboración de representaciones gráficas con los datos obtenidos, selección y elaboración cartográfica, establecimiento de correlaciones y tendencias.

d) Obtención de resultados y producción del desarrollo textual analítico-explicativo.

e) Elaboración de las conclusiones (reflexiones o consideraciones finales).

\section{Resultados}

La realidad geográfica del Chaco ha estado siempre vinculada con la existencia del bosque. Cabe aclarar que la denominación bosque chaqueño es una generalización, pues es sabido que esta llanura subtropical está conformada por distintas formaciones arbóreas (bajas, altas, cerradas,

Publicado en formato digital: Dr. Dante Edin Cuadra. LA PROBLEMÁTICA FORESTAL EN LA PROVINCIA DEL CHACO, ARGENTINA. UN ANÁLISIS DESDE LA GEOGRAFÍA. Revista Geográfica Digital. IGUNNE. Facultad de Humanidades. UNNE. Año 9. No 18. Julio - Diciembre 2012. ISSN 1668-5180 Resistencia, Chaco. En: http://hum.unne.edu.ar/revistas/geoweb/default.htm 
abiertas, mixtas y en galería) que, en ciertos ámbitos con condiciones topográficas, edáficas e hídricas particulares, se interrumpen para dejar lugar a sabanas de palmeras, parques, pastizales, arbustales, higrófilas y esteros.

Mapa № 1: Vegetación de la Provincia del Chaco.

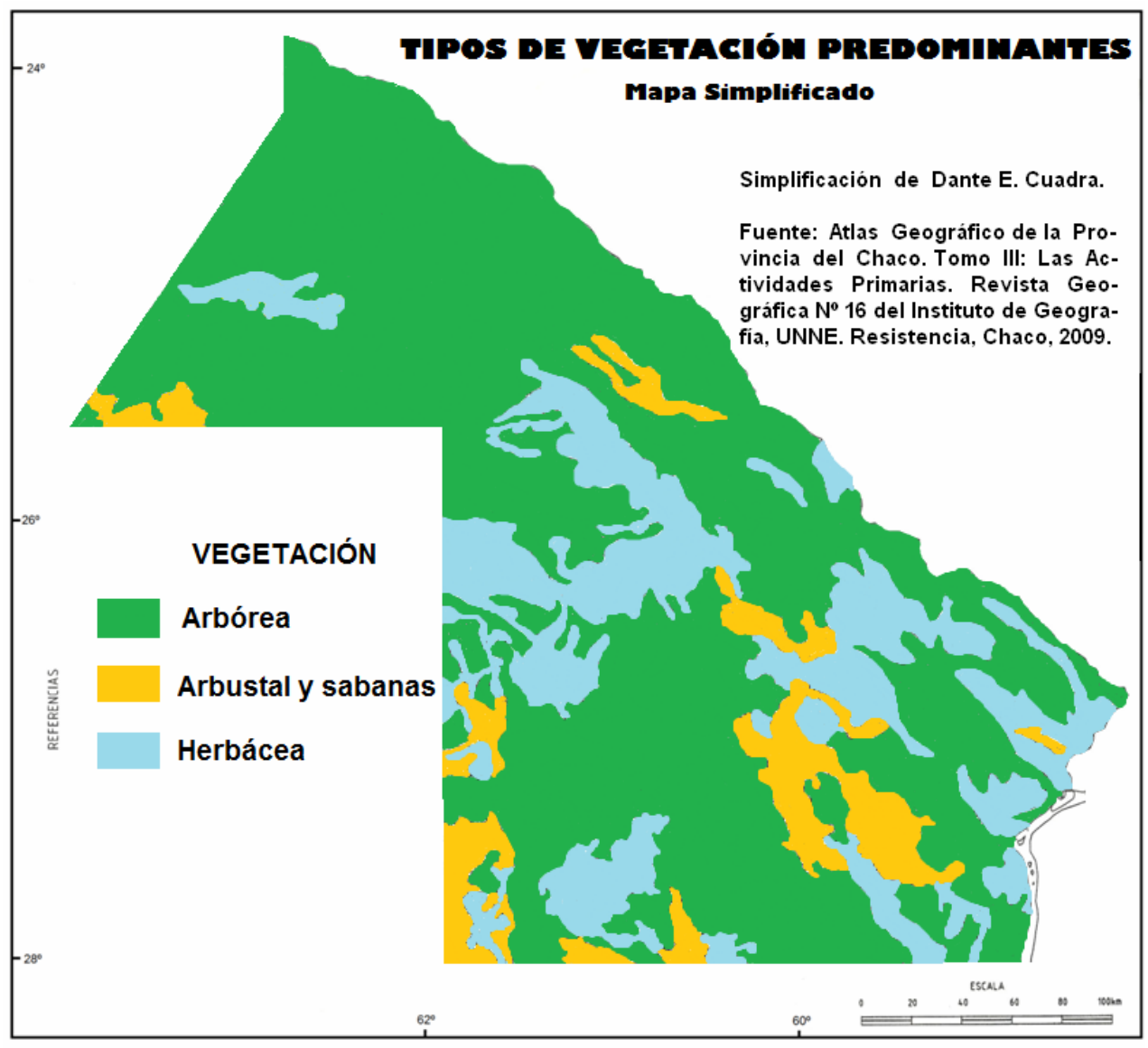

Local y regionalmente la población prefiere denominar a las formaciones arbóreas con el término "monte" (herencia hispánica), de donde se han desprendido algunas caracterizaciones como "Chaco montaraz", "San Buenaventura del Monte Alto" o "gato montero". Nada tiene que ver este tipo de vegetación con la clasificación fitogeográfica de la República Argentina, en la que el monte corresponde a una vegetación xerófila, baja y rala que se extiende sobre la diagonal árida desde Tucumán a Chubut. En este trabajo, se usarán indistintamente los términos bosque y monte.

La misma palabra "Chaco" (territorio de caza) hace referencia a un sistema eficiente de cacería montaraz practicado por las etnias autóctonas de la región que, a modo de cerco humano, se iba cerrando con el fin de que los animales confluyesen en un área despejada del bosque (pampa o abra) $\mathrm{y}$, ulteriormente, fueran atrapados con facilidad. El término "desierto verde" con que se denominaba a esta región en los tiempos precedentes a su conquista, que fuera luego mencionado por diversos autores como Guido Miranda, Carlos López Piacentini, Ramón Tissera o Enrique Bruniard, hacía referencia a la ausencia de hombres (blancos) en un área preeminentemente forestal. El nombre usual de la empresa multinacional que operó en el área durante la etapa colonizadora del oriente chaqueño fue, justamente, "La Forestal". Los ferrocarriles que a principios del siglo XX se constituyeron en puntales de colonización y poblamiento, fueron abriendo la espesura boscosa y sus rieles descansaron sobre durmientes de quebracho colorado extraídos del propio bosque. El Chaco 
ha sido el gran proveedor de maderas de gran parte del país, destinadas a alambrados (postes y varillas), artículos rurales, durmientes, adoquines, infraestructura portuaria, muebles, leña y carbón vegetal. El consumo de energía, hasta la llegada de la electricidad y del gas envasado, ha sido exclusivamente abastecido por las especies forestales y, aún hoy, estas prácticas continúan desarrollándose en áreas marginales o sectores rurales pobres. La construcción de viviendas en el territorio chaqueño ha demandado maderas durante el transcurso de toda su historia (vigas, tirantes, tablones, aberturas, cercos, portones e, inicialmente, paredes y pisos). Más dependientes aún de este recurso ha sido el emplazamiento de galpones, casillas o ranchos para peones, obrajes y campamentos en las zonas rurales. Asimismo, la implantación agroganadera se realizó a expensas de la tala de los bosques nativos y también en áreas de sabanas, abras o pastizales. En consecuencia, gran parte de la identidad y de la cultura, tanto material como simbólica del Chaco, está cimentada en la existencia de los bosques. Sin ellos, el Chaco perdería su esencia, su patrimonio natural, histórico y cultural.

Es indudable que el bosque nativo ha estado siempre sujeto a valoraciones materiales e inmateriales, las cuales difieren según los tiempos analizados y los sujetos y sectores de donde provienen tales valoraciones. En esta línea, se han podido reconocer etapas con actores y escenarios distintos a través del tiempo en el territorio del Chaco.

El bosque subtropical chaqueño: una variedad de paisajes.

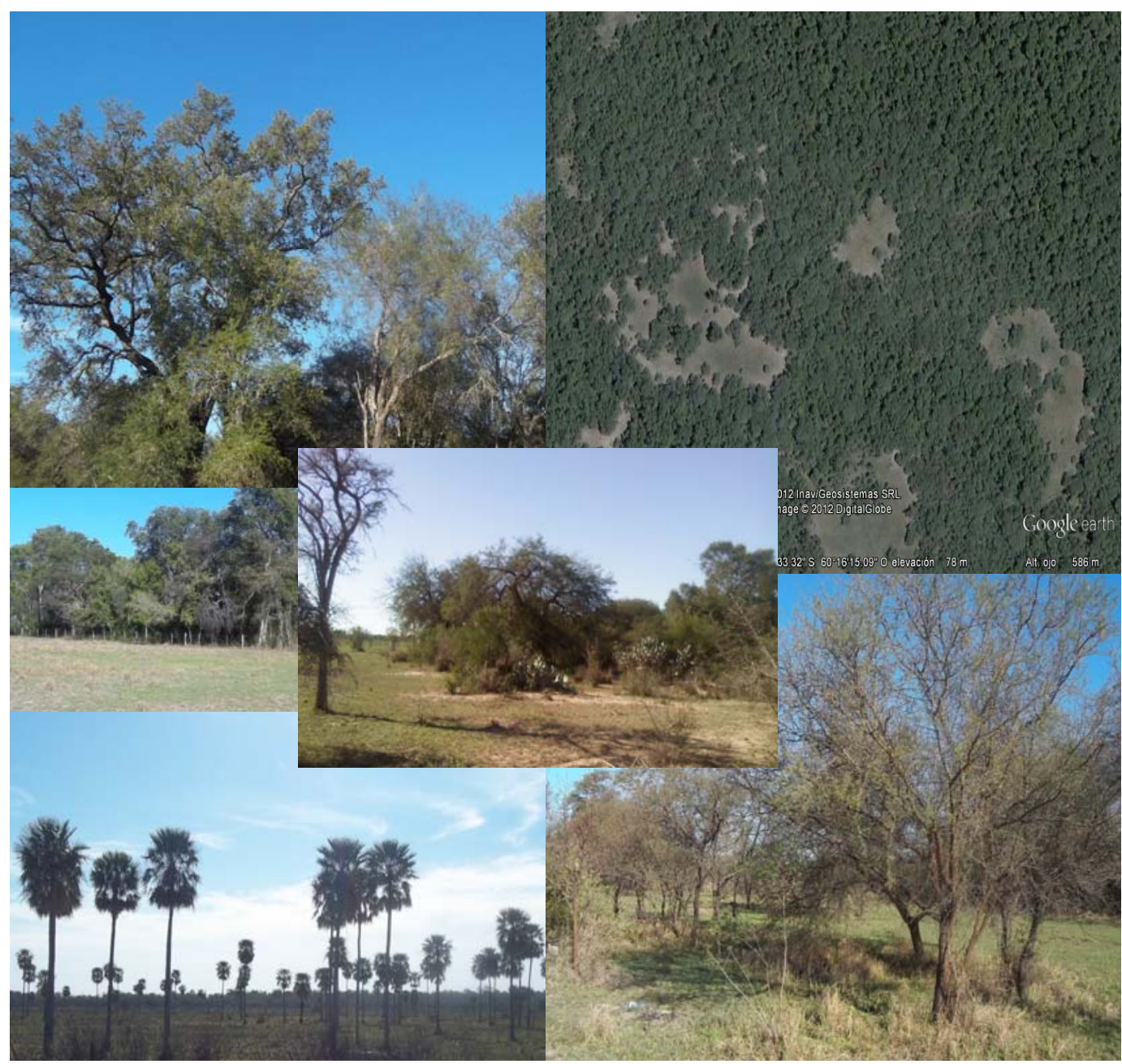

\section{El bosque chaqueño como hábitat de pueblos originarios}

Antes de la llegada del hombre blanco a esta región, los ecosistemas no experimentaban disturbios, ni alteraciones antropogénicas. La mayor parte del Chaco estaba conformado por 
diferentes formaciones boscosas (altas, bajas, cerradas, abiertas y de transición), aunque ciertas áreas deprimidas albergaban sabanas, pastizales y esteros, en tanto otras superficies con suelos compactos, salino-arcillosos (blanquizales) o con deficiencias hídricas sólo contenían coberturas herbáceas o arbustivas. A esos claros o interrupciones de las formaciones arbóreas se los denominó pampas (sin árboles) o abras (claro o lugar abierto dentro de un bosque).

Para las etnias originarias, que tradicionalmente habitaron la región, el bosque representaba esencialmente un "hábitat" (espacio de vida y, por tanto, de cultura), es decir, el ámbito donde encontraban cobijo, resguardo, medicinas, alimentos y demás recursos necesarios para su existencia, con el cual interactuaban física y simbólicamente. Se trataba de un espacio natural (sin alteraciones de los equilibrios ecosistémicos), donde podían asentarse o desplazarse de acuerdo con los ciclos estacionales del agua, la flora y la fauna y, asimismo, donde desarrollaban su organización sociocultural (cargada de creencias, interpretaciones y simbolismos), además de ser el escenario en el cual sostenían sus relaciones de amistad y de confrontación con otros grupos o etnias.

Sus prácticas de supervivencia (caza, pesca, recolección) y sus pautas culturales (formas de asentamiento, construcción de toldos y utensilios, desplazamientos, ritos y organización social), si bien variaban entre los numerosos grupos (tobas, mocovíes, wichís, chorotes, abipones) en todos los casos eran plenamente amigables con el medio natural. Por ejemplo, los tobas (qom) incluían en sus prácticas religiosas diarias oraciones y ruegos relacionados con las actividades que hombres $y$ mujeres desarrollaban en conexión con la naturaleza: el monte, el agua, el cielo, la luna, el sol, las estrellas, el viento y con los seres superiores que habitaban en estos elementos naturales.

\section{El bosque chaqueño como obstáculo natural de la conquista territorial}

Para el ideario de los grupos dominantes de la Argentina de fines del siglo XIX, el bosque chaqueño representó un verdadero "obstáculo" y, en tal sentido, dificultaba el despliegue de una rápida acción militar orientada a desplazar o eliminar a sus habitantes originarios que, amparados en ese medio, ofrecían una tenaz resistencia y hacían fracasar los distintos intentos de instalarse en el territorio, cualquiera sea el origen de los mismos: obrajeros, militares o religiosos.

La concepción de las autoridades nacionales hacia fines del siglo XIX (generación del '80), respecto de estas tierras y sus habitantes, fue tajantemente liberal y, a la vez, militarista. En su ideario económico de país agroexportador el "desierto verde" debía dominarse e incorporarse a la Argentina civilizada y productiva y, para tal fin, había que dar término a dos problemas que lo impedían: el indio y el bosque. Al primero de estos inconvenientes se lo atacó con siete columnas del ejército argentino en 1884, en la conocida campaña del General Victorica, venciéndose así las dificultades que el escenario boscoso presentaba para las operaciones bélicas, al término de las cuales se rayó la limpieza étnica en gran parte del territorio. Al segundo, se lo acometió a través de la explotación del quebracho colorado para la obtención del tanino destinado a la exportación, de la mano de ferrocarriles, decauvilles, campamentos, fábricas de tanino, habilitación de campos ganaderos y creación de pueblos, en una especie de co-gobierno entre autoridades territoriales y la megaempresa foránea La Forestal, como se la conocía a la firma inglesa The Forestal Land, Timber and Railways Company Limited.

\section{El bosque chaqueño como recurso natural}

Una vez "resuelto" el problema indígena y sancionada la Ley nacional 1532, en octubre de 1884, denominada de Organización de los Territorios Nacionales, por la cual se separaron Formosa y Chaco, el bosque fue valorado como un "recurso natural" que no sólo aportaría ingresos económicos, sino que su explotación constituiría una verdadera estrategia de penetración comunicacional a través de ferrocarriles y caminos, abriendo la brecha para la instalación de pueblos, colonias agrícolas, establecimientos industriales y campos ganaderos. En ese sentido se alentó la venida de empresas extranjeras para la producción de tanino, el ingreso de obrajeros para la producción de postes, tablones y durmientes, además de promover el acceso de inmigrantes europeos con cultura agrícola, con la finalidad de reemplazar al monte por cultivares.

El bosque dejó de ser considerado un obstáculo natural y, por el contrario, proliferaron los obrajes (auténticos campamentos dedicados exclusivamente a la extracción de maderas), que en épocas anteriores habían tenido múltiples dificultades al internarse en áreas dominadas por los aborígenes, quienes solían asediar estas instalaciones con ataques sorpresivos, matanzas e

Publicado en formato digital: Dr. Dante Edin Cuadra. LA PROBLEMÁTICA FORESTAL EN LA PROVINCIA DEL CHACO, ARGENTINA. UN ANÁLISIS DESDE LA GEOGRAFÍA. Revista Geográfica Digital. IGUNNE. Facultad de Humanidades. UNNE. Año 9. No 18. Julio - Diciembre 2012. ISSN 1668-5180 Resistencia, Chaco. En: http://hum.unne.edu.ar/revistas/geoweb/default.htm 
incendios. Estos establecimientos, bastante precarios y móviles, requerían caminos y medios de transportes (carruajes de tracción animal y, luego, camiones) para llevar los rollos y rollizos a los centros de consumo ubicados en las incipientes poblaciones del oriente chaqueño como Resistencia, Puerto Tirol y Puerto Vicentini. Asimismo, las fábricas de tanino se extendieron por el Este, Sudeste y Sudoeste del territorio, extrayendo la especie quebracho colorado chaqueño (Schinopsis balansae) y santiagueño (Schinopsis lorentzii), dando impulso y fortalecimiento al proceso demográfico y económico del Chaco, lo que no implicó que el mismo estuviera exento de arbitrariedades e injusticias, en un medio duro y de organización institucional incipiente.

Esta visión de apropiación, explotación y rentabilidad -muchas veces divorciada de toda jurisprudencia y sentido humanitario- que logró instalarse en el territorio, trajo consigo una carga de violencia social y política poco evaluada hasta ahora, totalmente opuesta a las concepciones y cosmovisiones de los pueblos originarios sobrevivientes y a los derechos más elementales en materia laboral y ciudadana que merecieron los empleados de las empresas tanineras. Este fue el preludio de un proceso que se desarrolló a lo largo del siglo XX, a través del cual se fue destruyendo paulatinamente hábitats y culturas resultantes de largas cadenas de interacción entre los grupos humanos y sus ambientes. El fenómeno, inicialmente fue más intenso en el oriente del Chaco, pero avanzó rápidamente hacia el centro y Sudoeste durante las primeras décadas del siglo XX.

\section{El bosque chaqueño como recurso geoestratégico}

Las líneas trazadas hacia el interior forestal del Chaco, a través de ferrocarriles y caminos, abriría la brecha para la instalación de pueblos, fábricas, colonias agrícolas, establecimientos industriales, campos ganaderos y la radicación de inmigrantes.

La explotación forestal representó el primer ciclo económico del Territorio Nacional del Chaco. Esta actividad financió gran parte del avance y colonización que desde el oriente y Sur se desarrolló hacia el centro en la primera parte del siglo XX, a la vez que generó una dinámica económica sin precedentes de la mano del ferrocarril, la industria taninera, los obrajes y, subsecuentemente la ganadería y la agricultura. Este proceso estratégico de apropiación y estructuración espacial, posibilitó el afianzamiento demográfico a través de poblados y colonias (Benítez, Popular, Novaró, Mixta, Uriburu, entre muchas). Las maderas fueron un factor relevante en la penetración territorial: fueron el insumo necesario para la instalación de vías férreas (durmientes), la apertura de caminos (puentes, alcantarillas), como combustible de las locomotoras y de uso doméstico, para el desarrollo de las actividades agropecuarias (postes, varillas, portones, tranqueras, corrales, bretes, mangas) e, incluso, la fabricación de viviendas. La economía chaqueña, hasta 1930, descansó en la explotación de los bosques; los actores sobresalientes en ese escenario eran: empresarios, pequeños y medianos obrajeros, dueños y empleados de aserraderos, hacheros aborígenes y criollos (muchos llegados de Corrientes, Santa Fe y Santiago del Estero), transportistas (carreros y luego camioneros), ferroviarios, empleados del sector taninero y changarines para tareas de carga y descarga. Al mismo tiempo, las tierras desmontadas alentaban la instalación de familias para desplegar la ganadería y la agricultura.

\section{El bosque chaqueño como variable de ajuste del sistema agropecuario}

El avance de la frontera agrícola, por medio del cultivo del algodón -entre 1930 y 1960- y de otros cultivos más tarde, da evidencias de una percepción productivista en la dirigencia política nacional y territorial, restándole al bosque toda importancia ambiental y cultural, sin preocupación por conservar áreas boscosas en distintos sectores del territorio. En el ideario de la época, el bosque era un elemento superabundante y casi un estorbo para la producción agropecuaria. La creación del Parque Nacional Chaco en el año 1954, con una superficie cercana a las 15.000 ha, fue una medida puntual dentro de la franja oriental más húmeda, que no tuvo correlato en otros lugares de la provincia con condiciones subhúmedas y semiáridas, que ameritaban su mantenimiento como ecosistemas de referencia dentro de un ámbito de rápida antropización.

Con el afianzamiento del cultivo del algodón se eliminaron enormes áreas boscosas en gran parte del Chaco: lograron salvarse aquéllas tierras de propiedad estatal (fiscales), las áreas que por su topografía (bajos, terrazas, desniveles) o condiciones edáficas (blanquizales, arcillas con elevada impermeabilidad) dificultaban la labranza o porque sus propietarios decidían mantener partes de sus campos con cobertura forestal (como fuente de provisión de maderas para uso doméstico, reparación

Publicado en formato digital: Dr. Dante Edin Cuadra. LA PROBLEMÁTICA FORESTAL EN LA PROVINCIA DEL CHACO, ARGENTINA. UN ANÁLISIS DESDE LA GEOGRAFÍA. Revista Geográfica Digital. IGUNNE. Facultad de Humanidades. UNNE. Año 9. No 18. Julio - Diciembre 2012. ISSN 1668-5180 Resistencia, Chaco. En: http://hum.unne.edu.ar/revistas/geoweb/default.htm 
de alambrados o para pastoreo y ramoneo en épocas invernales o de sequías). De esta forma, en gran parte de la herradura agrícola del Chaco, el bosque desapareció literalmente o quedó en una situación de alta vulnerabilidad.

El área que logró conservarse en condiciones más ventajosas fue la del Noroeste, conocida como "el Impenetrable Chaqueño", donde no se desarrolló la agricultura -al menos con la intensidad y continuidad observada en el resto de la provincia-, las tierras fiscales tienen mayor extensión y los centros poblados son poco numerosos y pequeños.

Con posterioridad a la crisis algodonera, luego de 1960, se produjo el desarrollo de la producción foresto-industrial en el centro del Chaco y se intensificaron los desmontes orientados a aumentar la superficie agrícola en áreas del Sudoeste y Noroeste provincial. A partir de la reforma constitucional de 1994, el surgimiento de nuevas legislaciones, el fuerte impulso logrado por la educación ambiental en los programas escolares, la toma de conciencia generalizada del valor ambiental, la difusión masiva de las tecnologías de las comunicaciones, las acciones de los organismos de derechos humanos y de las organizaciones no gubernamentales en materia de defensa de los derechos ambientales, sociales y culturales y, de hecho, la toma de conciencia de los grupos afectados, nos coloca en un "escenario de conflicto", donde según los actores y los intereses que éstos defienden, el bosque nativo es depositario de diferentes valoraciones, generalmente antagónicas e incompatibles, que no han logrado detener la pérdida de estos recursos, agravando la situación ambiental, social y cultural de nuestra provincia.

Mapa N²: Cobertura boscosa luego del proceso de explotación forestal y agropecuario.

\section{Distribución Forestal de la Provincia 2005}

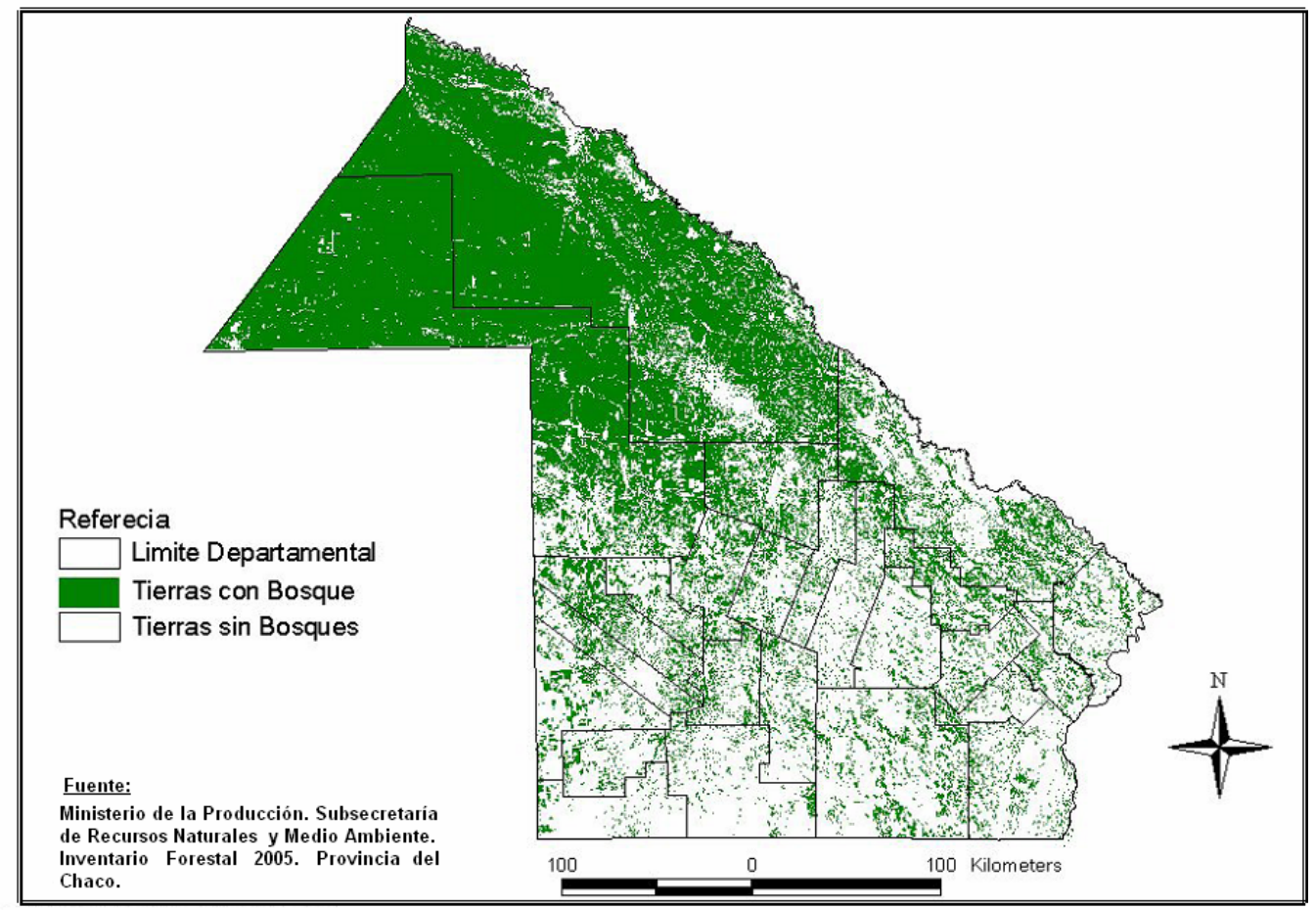

En el Chaco, a lo largo de su historia, hubo sectores que extrajeron maderas del bosque nativo destinadas al uso doméstico, producción de leña, carbón, postes, varillas, sumados a las demandas de carpinterías y aserraderos artesanales. Luego de 1980 se constituyeron unos incipientes aserraderos orientados a la fabricación de muebles en la ciudad de Machagai, que en pocos años concentró una gran cantidad de instalaciones que abastecía la demanda, no sólo regional, sino nacional. En el año 2008 se computaron 230 fábricas en dicha localidad y ya se sumaban sus vecinas Quitilipi (orientada a la producción de aberturas) y Presidencia de la Plaza (productos varios), sumando entre las tres alrededor de 450 establecimientos foresto-industriales. La demanda de

Publicado en formato digital: Dr. Dante Edin Cuadra. LA PROBLEMÁTICA FORESTAL EN LA PROVINCIA DEL CHACO, ARGENTINA. UN ANÁLISIS DESDE LA GEOGRAFÍA. Revista Geográfica Digital. IGUNNE. Facultad de Humanidades. UNNE. Año 9. No 18. Julio - Diciembre 2012. ISSN 1668-5180 Resistencia, Chaco. En: http://hum.unne.edu.ar/revistas/geoweb/default.htm 
materias primas, sobre todo del algarrobo (Prosopis nigra), aunque también de quebracho blanco (Aspidosperma quebracho blanco), urunday (Astronium balansae), lapacho negro (Tabebuia ipe), guaraniná (Bumelia obtusifolia), guayaibí (Patagonula americana), guayacán (Caesalpinia paraguariensis), ibirá pitá (Rupretchia laxiflora), tatané (Pithecellobium scalare), palo lanza (Phyllostylon ramnoides) y otras especies, afectó a gran parte de los bosques de la provincia, pero mayormente a las áreas más accesibles a los puntos de demanda de maderas, como puede verse en el siguiente mapa en los años finales del siglo XX e iniciales del XXI. Los bosques más afectados fueron los del cinturón centro-Sudoeste de la provincia, hacia donde avanzó la presión agropecuaria.

Estos años de pasaje de un siglo a otro vieron la implementación de fuertes medidas de raigambre neoliberal, que desalentaron a los pequeños productores y sedujeron a empresas dedicadas al agronegocio a radicarse en el Chaco -para alquilar y comprar tierras más baratas que en la región pampeana-. De este modo, se expandió la frontera agrícola hacia el extremo Sudoeste y áreas del Noroeste, sobre todo con el cultivo de la soja, cuyo precio internacional era altamente conveniente, aún en tierras marginales de inferior productividad, aunque favorecidas por un ciclo húmedo desplazado hacia el Oeste (Pértile V. y Torre Geraldi, A., 2011). A la agresividad ganancial de las empresas y a los visibles daños ambientales ocasionados, particularmente en las cubiertas boscosas del Chaco a partir de los años '90, se le sumó el uso indiscriminado de agrotóxicos (sospechados de producir graves efectos sobre la salud humana), ampliamente difundidos en los cultivos de la mencionada leguminosa.

Mapa Nº 3: Áreas deforestadas en el Chaco entre 1998 y 2002.

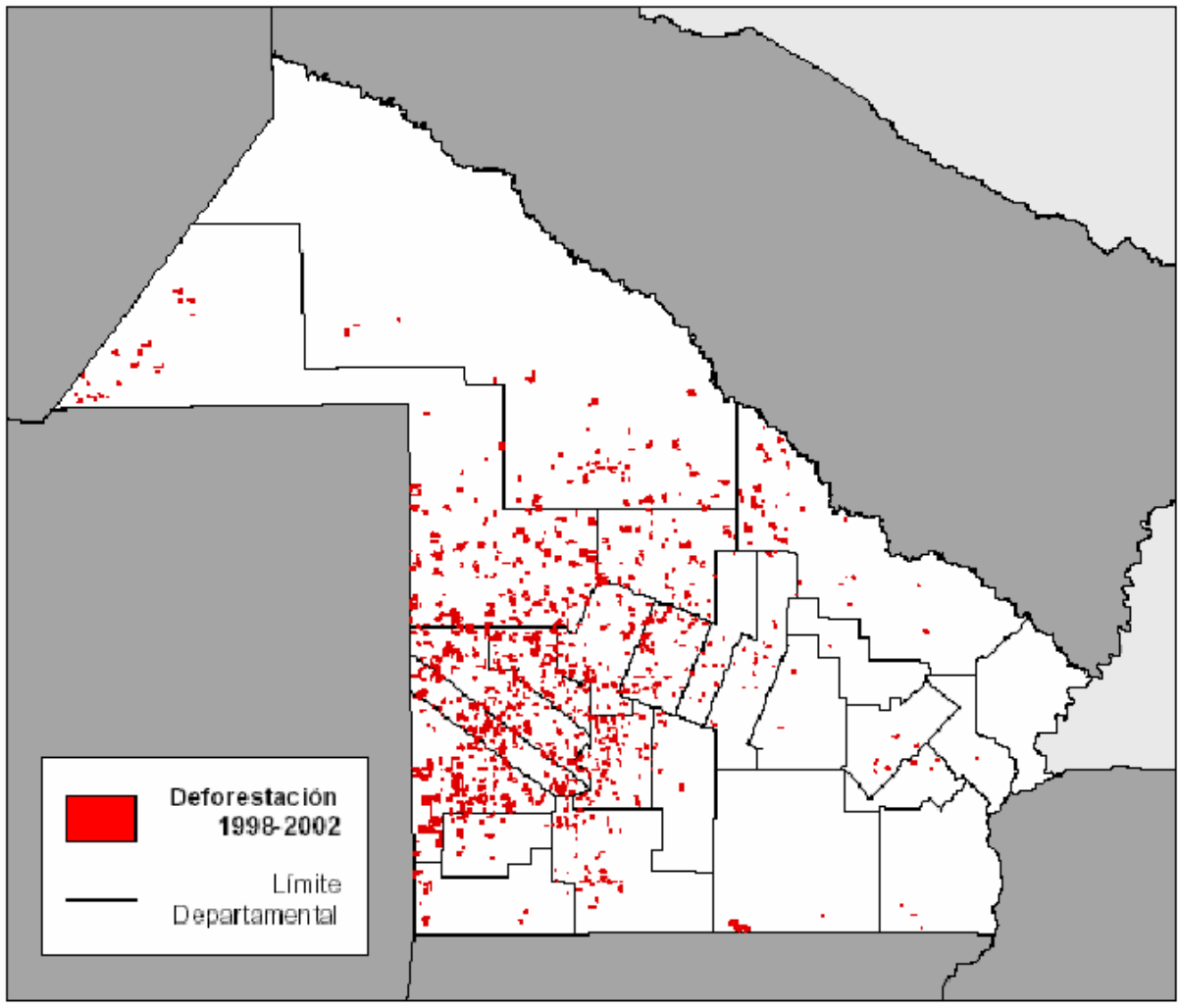

Fuente: Secretaría de Ambiente y Desarrollo Sustentable de la Nación. Dirección de Bosques.

De acuerdo con los datos oficiales, en los años '40 se intensificó la explotación maderera hasta alcanzar el millón de tn y, luego hasta inicios de los '80, fluctuó por debajo y por arriba de las 700.000 tn anuales. Al promediar esta década, la actividad experimentó una caída abrupta, por debajo de las 
300.000 tn/año, pero desde ese momento hasta el 2006 mostró un sostenido crecimiento, sobre todo a partir de 1998, cuando superó por amplio margen el millón de tn. Entre 2007 y 2010 la producción tuvo una desaceleración en torno a 1.100 .000 tn por año, atribuible a la sanción y promulgación de la nueva Ley de Bosques y a la decisión de suspender los desmontes hasta tanto la provincia culminara su Ordenamiento Territorial de sus bosques nativos.

\section{Gráfico N 1:}

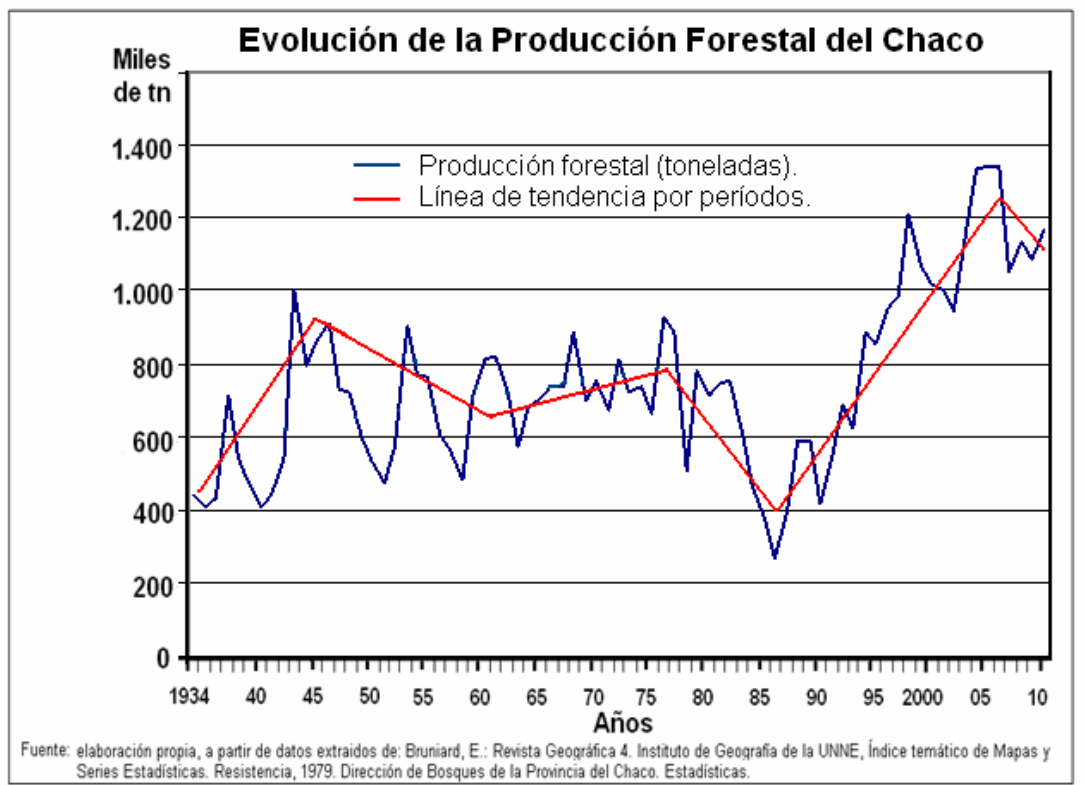

La producción de tanino, a partir de la explotación del quebracho colorado chaqueño (Schinopsis balansae) y quebracho colorado santiagueño (Schinopsis lorentzii) lleva más de un siglo en el Chaco. Esta actividad ha sido la prolongación del proceso vivido anteriormente en el Norte santafesino y ha tenido una incidencia relevante en los inicios de la historia política, económica, social y cultural del Territorio Nacional del Chaco.

La actuación de grandes empresas en la zona, las prácticas autoritarias y esclavistas que desarrollaron, la implantación de obrajes, fábricas, vías férreas, caminos, pueblos y campos ganaderos, le dio una dinámica inusitada a este espacio geográfico durante la primera mitad del siglo XX. De las dieciséis fábricas que existieron, hoy sólo dos se mantienen en actividad, localizadas en La Escondida y Puerto Tirol. El volumen de producción fluctúa en torno a las 50.000 tn anuales desde mediados del ' 80 , cuando empezó a acentuarse la crisis de este sector industrial. La demanda de rollizos de quebracho colorado para producir extracto de tanino y furfural es de alrededor de 200.000 tn anuales en la última década. Es previsible que a este ritmo de explotación, que conlleva a una gradual disminución de la materia prima disponible y, ante las nuevas legislaciones de protección ambiental vigentes, se llegue a un punto en los próximos años, en el que la actividad tendrá serias dificultades para continuar operando.

\section{Gráfico N²:}




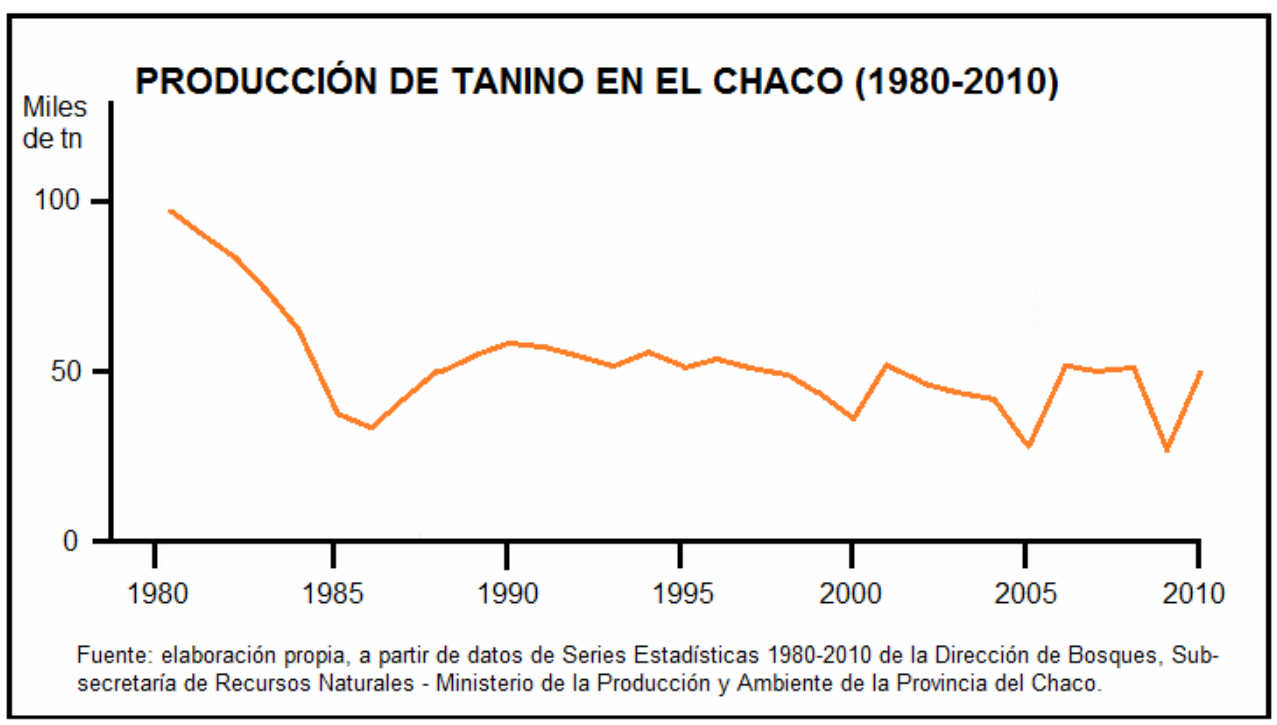

\section{La nueva Ley de Bosques}

En la reforma constitucional de 1994 se incorporaron principios de protección ambiental, desarrollo sustentable y valoración a los pueblos originarios y sus culturas. Ello permitió que, tanto a nivel nacional como provincial, se sancionaran normas específicas, como ha sido la Ley № 26.331/07 de Presupuestos Mínimos de Protección Ambiental para el enriquecimiento, la restauración, conservación, aprovechamiento y manejo sostenible de los Bosques Nativos, que fuera reglamentada en 2009.

El gobierno del Chaco, a través del Comité Técnico para la Categorización de los Bosques Nativos realizó, hacia finales de 2008, la Propuesta de Ordenamiento Territorial para la provincia. La misma, fue socializada a través de talleres desarrollados en distintas localidades de la provincia y, posteriormente, presentada a la Legislatura. Numerosas organizaciones enunciaron observaciones (Greenpeace, Fundación Vida Silvestre Argentina, Fundación Ambiente y Recursos Naturales, Fundación Biodiversidad, Taller Ecologista y Red Yaguareté), lo que llevó al propio poder Ejecutivo a vetar algunos artículos. Finalmente, la provincia del Chaco aprobó su Ordenamiento Territorial por Ley provincial $N^{\circ} 6.409$, en septiembre de 2009. Dicho ordenamiento establece: 501.958 hectáreas en la Categoría I - Rojo (áreas protegidas de muy alto valor de conservación, donde no se permite el desmonte, ni el aprovechamiento forestal y silvopastoril), 3.066.780 hectáreas en la Categoría II Amarillo (aprovechamiento forestal y silvopastoril sustentable) y 1.531 .575 hectáreas en la Categoría III - Verde (permite su desmonte parcial para el desarrollo agropecuario).

Mapa № 4: Zonificación de los Bosques Nativos según valor de conservación, resultante de ley $\mathbf{N}^{\circ}$ 26.331/07 de Presupuestos Mínimos de Protección Ambiental. 


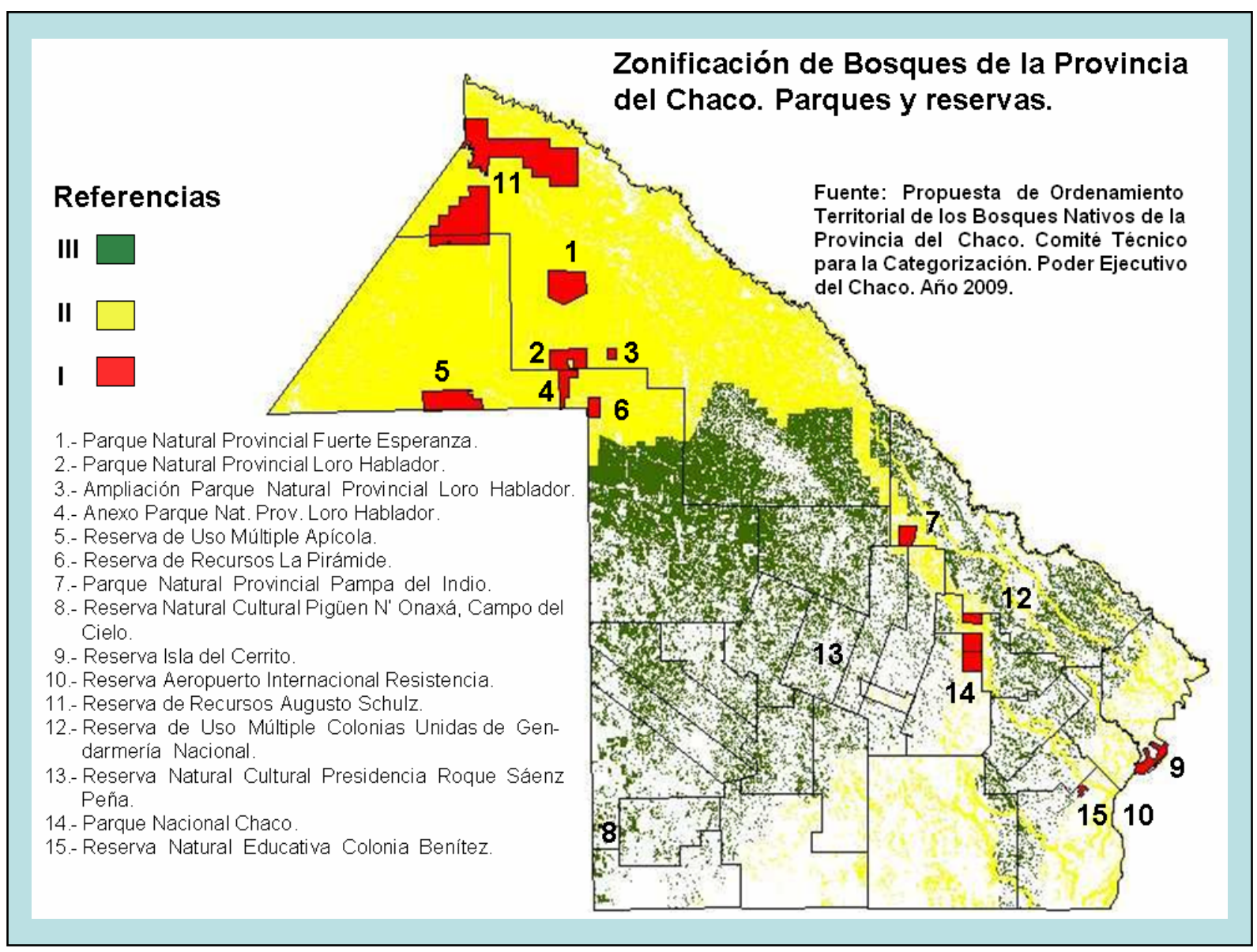

En el Chaco, la Ley de Bosques 26.331/07 se cumple con ciertas dificultades, dado que se carece de ciertas especificaciones técnicas, se requeriría mayor presupuesto del orden nacional para su ejecución y, en términos funcionales y operativos, le toca convivir con otras legislaciones provinciales que, en ocasiones, generan dificultades de interpretación a la hora de su implementación.

\section{Múltiples intereses y alta conflictividad}

Más allá de que la provincia del Chaco, tal como lo contempla la citada ley nacional de bosques, haya delimitado zonas verdes (explotables), amarillas (manejo racionalizado) y rojas (intocables), la pérdida de los bosques, al menos en las dos primeras, continúa su curso. El gobierno ha vacilado -en los años inmediatamente posteriores a la promulgación de la ley- en tomar posturas severas ante los fuertes intereses sectoriales en juego, al tiempo que la corrupción instalada en el tejido social no escapa a esta temática, donde la legalidad y la ilegalidad se entrecruzan permanentemente. La cuestión, en sí misma aparece como compleja, por dos motivos: a) la gran cantidad de actores involucrados: organismos como Dirección de Bosques, Instituto Nacional de Tecnología Agropecuaria (INTA), Instituto de Investigaciones Forestales y Agropecuarias (IIFA), Servicio Nacional de Sanidad Animal (SENASA), productores agropecuarios, productores madereros, industriales madereros, transportistas, Policía Rural, Policía Ecológica, reparticiones ambientales, organizaciones no gubernamentales (ONGs), pueblos originarios, empresas de desmontes, etc.; b) la gran superficie sobre la que se distribuyen los bosques, muchas de ellas con escasa o nula población, caminos poco accesibles y, por ende, dificultades para efectuar los controles de guías y cargas. A ello se agrega una gran propensión a cometer ilegalidades, por parte de muchos de los actores participantes, que evaden, falsean u ocultan información, dan o reciben coimas e, incluso, ejercen ciertos tipos de violencia para obtener los beneficios perseguidos.

Publicado en formato digital: Dr. Dante Edin Cuadra. LA PROBLEMÁTICA FORESTAL EN LA PROVINCIA DEL CHACO, ARGENTINA. UN ANÁLISIS DESDE LA GEOGRAFÍA. Revista Geográfica Digital. IGUNNE. Facultad de Humanidades. UNNE. Año 9. No 18. Julio - Diciembre 2012. ISSN 1668-5180 Resistencia, Chaco. En: http://hum.unne.edu.ar/revistas/geoweb/default.htm 
Revista Geográfica Digital. IGUNNE. Facultad de Humanidades. UNNE. Año 9. № 18. Julio - Diciembre 2012. ISSN 1668-5180 Resistencia, Chaco

La problemática forestal, como otros recursos naturales, está atravesada por diferentes sectores, actores e intereses. Por un lado, por ser un componente territorial, se encuentra bajo jurisdicción político-administrativa de un Estado, el que -a su vez- se desenvuelve en varios niveles: nacional, provincial y municipal; asimismo, las funciones que le competen al Estado se reparten en sus tres poderes: Ejecutivo, Legislativo y Judicial. Existen reparticiones oficiales encargadas de la preservación de los ambientes, como la Administración de Parques Nacionales y la Subsecretaría de Recursos Naturales del Ministerio de Producción y Ambiente del Chaco; también órganos ejecutivos a nivel nacional, como la Secretaría de Ambiente y Desarrollo Sustentable, la Dirección de Bosques, dependiente de la Dirección Nacional de Ordenamiento Ambiental y Conservación de la Biodiversidad. En la esfera provincial se encuentran diferentes entes, como la Dirección de Bosques y el Instituto de Colonización (dentro del Ministerio de Producción), la Dirección de Catastro y Cartografía (como área de la Subsecretaría de Hacienda y Finanzas del Ministerio de Economía, Industria y Empleo) y la Dirección de Suelos (dependiente de la Subsecretaría de Recursos Naturales).

El mismo Estado ha instituido una maraña de estamentos de distintas jerarquías y roles, a veces contrapuestos, con una pesada burocracia -típica de la administración argentina-, que dificulta la gestión clara y eficiente en materia forestal. A su vez, cada una de las reparticiones ejecuta proyectos y programas sin una visión holística. A modo de ejemplo, el siguiente listado corresponde solamente a la Dirección de Bosques en el nivel nacional:

-Proyecto Información y análisis para el manejo forestal sostenible.

-Unidad de Manejo del Sistema de Evaluación Forestal.

-Proyecto Bosques Nativos y Áreas Protegidas.

-Programa Productos Forestales No Madereros.

-Programa Nacional de Estadística Forestal.

-Programa Nacional de Bosques Modelo.

-Área Normativa y Legislación Forestal.

-Ordenamiento Territorial de los Bosques Nativos.

A ellos debemos agregarles, por citar sólo algunos, el Programa Nacional de Sanidad Forestal del SENASA, el Programa Cambio Rural -Componente Forestal- (perteneciente al Ministerio de Agricultura, Ganadería y Pesca de la Nación, operativizado por el INTA) y el Plan Provincial de Expansión Forestal (del Instituto de Investigaciones Forestales y Agropecuarias, dependiente del Ministerio de Producción del Chaco).

Es responsabilidad estatal impulsar las normas legales, implementar los mecanismos de control y ejecutar las medidas pertinentes para garantizar el bien general y particular de sus ciudadanos actuales y de las próximas generaciones. Asimismo, el Estado cumple el rol de policía, con el fin de evitar delitos contra bienes públicos y privados, como la tala no autorizada, el transporte de maderas sin emisión de las guías correspondientes o el incumplimiento de lo estipulado por las autorizaciones de Aprovechamiento Forestal y, para ello, cuenta con la Policía Rural, la Policía Ecológica, a veces auxiliada por Policía Federal y Gendarmería Nacional, además de los funcionarios de la Dirección de Bosques de la provincia y del Instituto de Colonización.

Allí no termina el rol del Estado, pues es también propietario de tierras -denominadas fiscales-, con capacidad de hacer concesiones, venta o arrendamiento a particulares u organizaciones sociales o comunitarias. En este sentido, en los últimos años se ha denunciado una gran cantidad de operaciones poco claras en relación con el otorgamiento de tierras fiscales a particulares y a grupos empresariales, que se dirimen actualmente en el ámbito de la justicia. El único organismo provincial responsable de otorgar títulos de propiedad de tierras que hasta ese momento hayan sido fiscales es el Instituto de Colonización (el cual podría desaparecer próximamente, dado que el Ejecutivo Provincial analiza la posibilidad de absorberlo mediante la creación del Instituto de Gestión de Tierras, dentro del Ministerio de Desarrollo Territorial). Los procesos judiciales que se han venido desarrollando en los últimos años tienen tres orígenes: mal desempeño de funcionarios y personal de organismos públicos, atribuciones no pertinentes de estamentos del Estado en el otorgamiento de tierras $\mathrm{y}$, con frecuencia, maniobras ilegales de particulares o grandes empresas, que implican: usurpación de tierras fiscales, explotación de las mismas, fraudulencia de documentos públicos, despliegue de acusaciones y denuncias contra funcionarios públicos y, además, estrategias de dilatación de los procesos judiciales por identificación de errores de procedimiento; ello les permite, mientras tanto, proseguir con el saqueo de los bienes públicos, obteniendo beneficios importantes, más allá de los resultados a los que se arriben en los tribunales.

Publicado en formato digital: Dr. Dante Edin Cuadra. LA PROBLEMÁTICA FORESTAL EN LA PROVINCIA DEL CHACO, ARGENTINA. UN ANÁLISIS DESDE LA GEOGRAFÍA. Revista Geográfica Digital. IGUNNE. Facultad de Humanidades. UNNE. Año 9. No 18. Julio - Diciembre 2012. ISSN 1668-5180 Resistencia, Chaco. En: http://hum.unne.edu.ar/revistas/geoweb/default.htm 
Aparte del Estado, se hallan las organizaciones civiles, entre las que se citan:

a) Los pueblos originarios: en la provincia del Chaco han sobrevivido a la conquista y colonización tres etnias: tobas (qom), mocovíes (moqoit) y wichís o matacos. A partir de la última década del siglo $X X$, luego de que sus derechos fueran incorporados por la reforma constitucional argentina del año 1994, han logrado organizarse en asociaciones y llevar adelante sus justos reclamos, entre los que se encuentra la posesión comunitaria de tierras y la preservación de sus hábitat milenarios, sobre todo del bosque. La asociación qom Meguesoxochi logró que el gobierno del Chaco devolviera a esta etnia 150.000 ha, entre los ríos Teuco y Bermejito, que ya en 1924 el presidente Alvear les reconociera. Otras asociaciones son: Nueva Población, Paso Sosa, Nuevo Futuro, Paraje La China, Olla Quebrada, El Simbolar, El Algarrobal, Las Palomas, Palma Sola, Miraflores, Raíz Chaqueña, Colonia Aborigen Chaco, La Matanza Lote 17, Lote 20, J.J. Paso, Cacique Catán, Qomlashepí, Laguna Pato Xuotaxanie Xaie, Paraje El Pindó, Nueva Esperanza, El Salteño, Barrio Nueva Población Lote 38 Dalaxaic N'ma', 12 de Octubre, Las Tolderías, San Lorenzo, Beragañik, La Pampita, Lote 40 "B", La Matanza, El Pastoril, Los Mocovíes de Peguriel, Indígena La Leonesa, Maipú, Villa Margarita, Barrio Belgrano, Barrio Teresita, La Isla, Asociación Qompi, Asociación Cacique Taigoyic, Cacique Pedro Martínez, Asociación Chaic, Iglesia Cuadrangular de La Leonesa y las Comisiones Isla Soledad, Barrio Nam Qom-Quinta 8, Barrio Pablo Sexto y Quinta 14-Tacac. También hay instituciones que los agrupan, como el IDACh (Instituto del Aborigen Chaqueño), que es un ente autárquico dentro de la esfera del Poder Ejecutivo del Chaco.

b) Las organizaciones ambientalistas: estas organizaciones no gubernamentales han cobrado un gran protagonismo en los últimos años, sobre todo a partir de la intensa expansión del cultivo de soja sobre tierras de desmontes. Las que han sostenido una actitud crítica, tanto sobre el gobierno provincial como sobre las megaempresas del agro y los explotadores forestales han sido Greenpeace (ambientalista) y el Centro de Estudios Sociales Nelson Mandela (de derechos humanos), que han acusado y denunciado en reiteradas oportunidades a funcionarios, organismos del Estado y particulares por favorecer el desmonte, producir contaminación y perjudicar, tanto a pequeños productores como a comunidades y culturas autóctonas.

c) Los sectores privados: confluyen en este grupo, actores muy diversos, que incluye -en principio- a los productores o explotadores forestales (quienes pueden formar parte de asociaciones de productores forestales o actuar en forma individual), pero además intervienen otros sujetos, como los propietarios de montes, las empresas encargadas del desmonte (dueños de topadoras, guinches de carga, tractores, etc.), los responsables de industrias forestales (fábricas de tanino, aserraderos, carpinterías y otros establecimientos dedicados a producir aglomerados, pellets o abonos, por ejemplo), talleres de montaje, pulido, laqueado, torneado y artesanías, pequeños y medianos productores agropecuarios y grandes empresas del agro, que requieren del desmonte para llevar a cabo sus actividades.

d) Los sectores conexos: existe una amplia gama de sectores que obtienen, directa o indirectamente, beneficios de la actividad forestal; entre ellos se pueden mencionar: los cuentapropistas, empleados registrados, no registrados y changarines que participan de toda la cadena forestal, que incluye una diversidad de actividades que va desde el propio obraje (motosierristas, tractoristas, maquinistas, hacheros, descortezadores, cargadores, camioneros), pasando por las fábricas, talleres, secaderos, negocios de herramientas e insumos, transportistas, agremiaciones, consultoras, profesionales (técnicos, contables, jurídicos), instituciones vinculadas (tecnológicas, de investigación y educación), intermediarios, bancos y proveedores de servicios. El siguiente esquema muestra cómo se ordenan estos actores:

Publicado en formato digital: Dr. Dante Edin Cuadra. LA PROBLEMÁTICA FORESTAL EN LA PROVINCIA DEL CHACO, ARGENTINA. UN ANÁLISIS DESDE LA GEOGRAFÍA. Revista Geográfica Digital. IGUNNE. Facultad de Humanidades. UNNE. Año 9. No 18. Julio - Diciembre 2012. ISSN 1668-5180 Resistencia, Chaco. En: http://hum.unne.edu.ar/revistas/geoweb/default.htm 


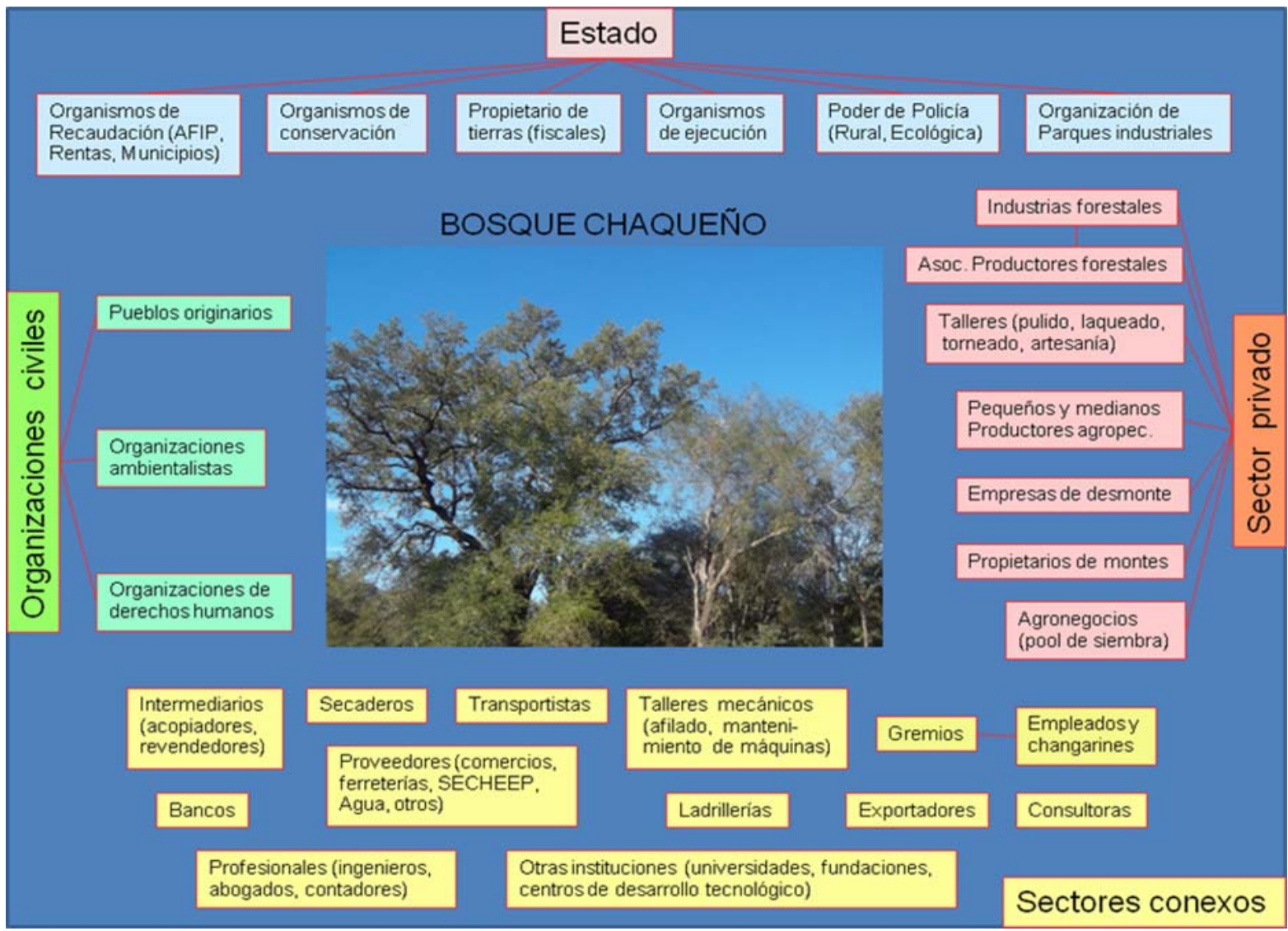

\section{Los problemas del uso sustentable}

Actualmente, la provincia del Chaco tiene una cobertura forestal que representa casi la mitad de su superficie, según los organismos oficiales, sumando los bosques puros y los que acusan una historia de empobrecimiento por tala selectiva u otros usos. Pero, las estadísticas resultantes de los Inventarios Forestales de los años 2005 y 2011 son objeto de algunos cuestionamientos por parte de organizaciones no gubernamentales, sobre todo del Centro de Estudios e Investigación Social Nelson Mandela, de Derechos Humanos. Las críticas giran en torno a la veracidad de los datos, su bajo grado de detalle, alcances muy difusos y escaso trabajo en el terreno. Más allá de esas polémicas, lo que resulta difícil comprender es que entre los años 2005 y 2011 la cobertura forestal se haya mantenido estable, según los datos de los Inventarios Forestales, cuando los planes de forestación y reforestación no representan aún cifras significativas y las tasas de deforestación han sido muy importantes en el Chaco, sobre todo en las dos últimas décadas (superiores -en el promedio 19982010- a las 100.000 ha en los datos oficiales y estimadas entre 300.000 y 240.000 por las ONGs). En 1980, el espacio cubierto por bosques nativos fue de 5,5 millones de ha en el Chaco y, posteriormente, la Dirección de Bosques de esta provincia, como resultado de sendos inventarios forestales, dio a conocer que en 2005 y 2011 la cobertura alcanzaba los 4,9 millones de ha. Ello equivaldría a una disminución de 600.000 ha de bosques nativos en veinticinco años (entre 19802005) y, luego, se mostró invariable durante seis años (2005-2011). En el marco de este debate, el Centro de Estudios Sociales Nelson Mandela sostiene que en 2004 las existencias cubrían una superficie de 3,9 millones de ha, es decir, que habrían sufrido una reducción de 1,6 millones de ha en un lapso de veinticuatro años y, más tarde, entre 2004 y 2010 se perdieron 300.000 ha, quedando un remanente de 3,6 millones de ha para el 2010.

El siguiente gráfico muestra claramente esta controversia, en medio de la cual queda una brecha de 1,3 millones de ha. que no son -para nada- despreciables, pues estarían determinando dos situaciones muy diferentes: que la mitad de la superficie provincial estaría cubierta por bosques nativos (discurso oficial) o solamente algo más de un tercio (versión extraoficial).

Publicado en formato digital: Dr. Dante Edin Cuadra. LA PROBLEMÁTICA FORESTAL EN LA PROVINCIA DEL CHACO, ARGENTINA. UN ANÁLISIS DESDE LA GEOGRAFÍA. Revista Geográfica Digital. IGUNNE. Facultad de Humanidades. UNNE. Año 9. No 18. Julio - Diciembre 2012. ISSN 1668-5180 Resistencia, Chaco. En: http://hum.unne.edu.ar/revistas/geoweb/default.htm 
Gráfico No 3:

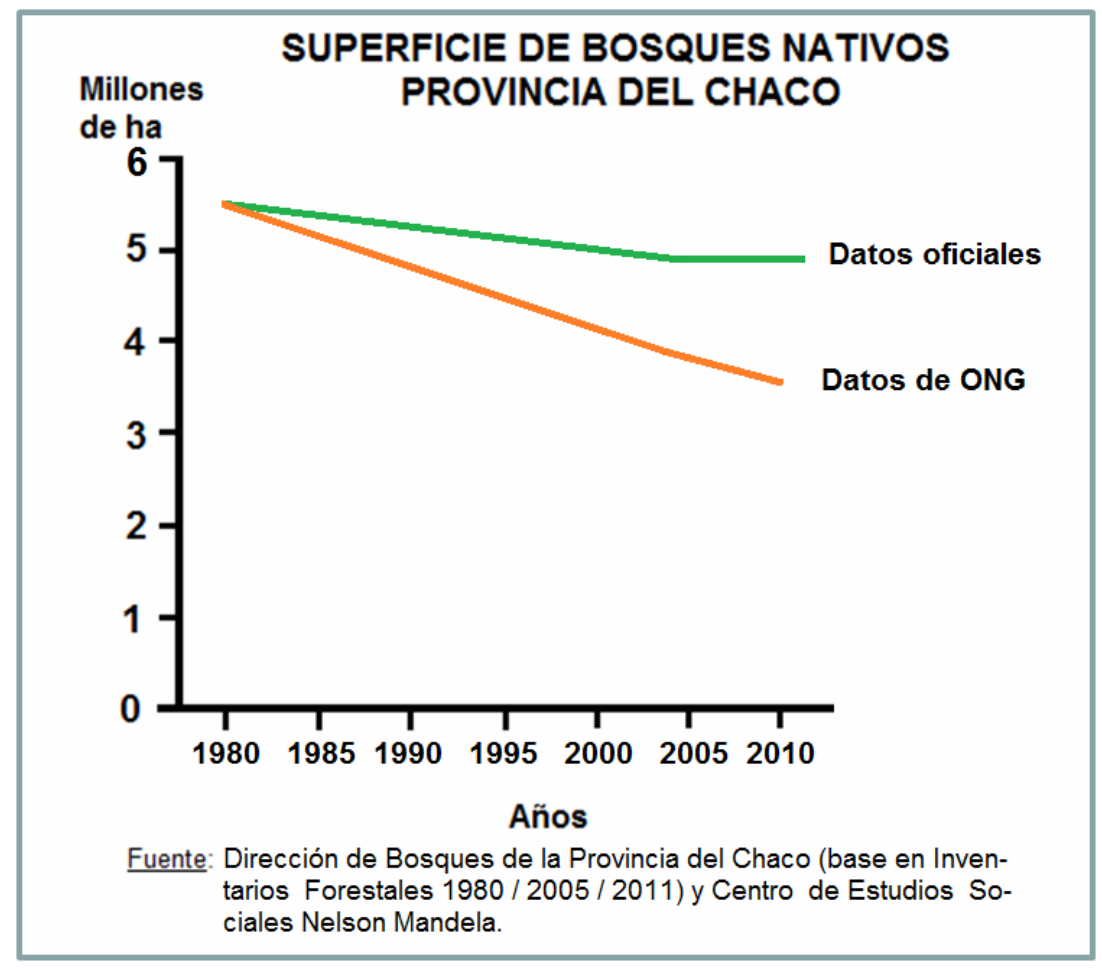

Es posible que los datos del gobierno provincial no sean exactos, ya que es difícil sostener que a una tasa de extracción anual de 1,2 millones de tn anuales y a un ritmo de emisión de autorizaciones de aprovechamiento forestal que fluctúa entre 800 y 1.500 permisos por año (más de 100.000 ha anuales), no tengan ninguna implicancia en la superficie o cobertura boscosa, que entre 2005 y 2011 permanecerían inalterables. Por otro lado, probablemente, las ONG exageren en sus apreciaciones, además de no contar con los elementos técnico-instrumentales y recursos humanos idóneos para brindar valores confiables. Es esperable, desde una reflexión razonable y un análisis de las tendencias integrales (que incorpora los datos registrados y estima el volumen de explotaciones clandestinas), que la provincia del Chaco, en el año 2012, disponga de una superficie forestal del orden de los 4,2 a 4,5 millones de ha.

Desde lo estrictamente ideológico, existen sujetos y sectores que defienden posturas conservacionistas, como Greenpeace, Vida Silvestre, Acdi, Farn, Fundación Gran Chaco, Centro de Estudios Sociales Nelson Mandela y numerosas comunidades originarias (una de ellas Meguexosochi- o, al menos su dirigencia, se halla fuertemente cuestionada por permitir el desmonte en el área Teuco-Bermejito en tierras de propiedad comunitaria qom, en connivencia con empresarios y políticos). En tal sentido, el propio IDACh ha hecho público su desacuerdo con este tipo de maniobras. Algunos estamentos del Estado estrechan filas, por la propia pertinencia de sus funciones, como la Administración de Parques Nacionales o la Dirección de Fauna y Áreas Naturales Protegidas (dependiente de la Subsecretaría de Recursos Naturales del Ministerio de Producción de la provincia del Chaco) y bregan por la conservación y protección de áreas que, con el tiempo -sobre todo en la década del ' 90 y la siguiente-, fueron adquiriendo un status legal para sostener un carácter intangible (ver mapa $N^{\circ} 4$ ), aunque los niveles de controles y resguardos en las áreas más alejadas no son aún suficientes.

Un segundo grupo aboga por el uso sustentable de los bosques: aprovechamiento forestal pautado por técnicos y organismos específicos, desarrollo de prácticas silvo-pastoriles, usos agropecuarios con resguardo de franjas o proporciones de bosques y forestación o reforestación con especies nativas (en esta línea, desde lo discursivo, el Estado intenta posicionarse a través de varios de sus organismos: Dirección de Bosques, INTA, IIFA, entre otros). 
Revista Geográfica Digital. IGUNNE. Facultad de Humanidades. UNNE. Año 9. No 18. Julio - Diciembre 2012. ISSN 1668-5180 Resistencia, Chaco

Finalmente, se observa un sector netamente extractivista, que continúa viendo al bosque como un estorbo para la producción agropecuaria o como un recurso natural que debe continuar abasteciendo las demandas del mercado forestal hasta tanto se encuentre disponible (vale decir, hasta su agotamiento), lo que se ha dado en llamar una "concepción minera". En esta última postura, consciente o inconscientemente, se encolumnan los grandes empresarios sojeros, numerosos emprendedores agropecuarios, explotadores forestales, empresas de desmontes, industriales madereros, transportistas forestales y determinados sectores minoritarios que obtienen beneficios de estas explotaciones.

El primer problema que se detecta es el doble rol que intenta desplegar el Estado provincial: desde lo discursivo existe el montaje de un aparato publicitario que brega por la defensa del bosque chaqueño, la difusión de planes y programas de protección/ampliación forestal, de rastrillajes, identificación y castigos para quienes transgreden las leyes (detención, decomisos, multas) y la incorporación de tecnologías de avanzada (monitoreo satelital) para el control de la cobertura boscosa y la rápida intervención de los organismos correspondientes en los lugares donde se detectan transgresiones o delitos. Pero, por otro lado, la determinación de zonas verdes, amarillas y rojas en función de la Ley de Bosques № 26.331/07, desde la visión de algunas organizaciones ambientalistas, ha dejado al patrimonio forestal de la provincia en situación de alta vulnerabilidad. Lo cierto es que, partiendo de los mismos datos oficiales, las zonas rojas (intocables) representan superficies ínfimas (alrededor de un $5 \%$ de la superficie del Chaco), correspondientes a parques y reservas nacionales y provinciales, en tanto es muy amplia la zona verde, dentro de la cual quedan muy pocas, fragmentadas y empobrecidas áreas boscosas (15\%). Las zonas amarillas también son extendidas y abarca grandes áreas del Noroeste provincial, donde aún existe una importante riqueza forestal (31\%), pero si bien en ellas se prohíbe el desmonte, sí se permiten diferentes tipos de aprovechamiento forestal que implicará la eliminación, simplificación o transformación de las condiciones originales, un proceso difícil de atenuar cuando se da inicio.

En concatenación con lo anterior, el Plan Ganadero del Chaco tiene por objetivo duplicar el stock ganadero para el año 2015 y pasar de las 2.600 .000 cabezas actuales a 5 millones. El avance de la ganadería puede significar la segmentación y la pérdida de una gran porción de "El Impenetrable" en el mediano plazo, que representa un área forestal de casi 4 millones de ha, considerando la totalidad de la región de la llanura chaqueña semiárida, hábitat de especies en peligro de extinción, como el oso hormiguero, el tatú carreta y el yaguareté. Actualmente, los departamentos Noroccidentales del Chaco, Almirante Brown y General Güemes, albergan algo menos del $70 \%$ de las existencias forestales y son las jurisdicciones que concentran la mayor superficie de tierras fiscales de la provincia.

El gobierno del Chaco ha hecho explícita su expectativa de extender el área agropecuaria. En el sitio del Ministerio de Producción y Ambiente del Chaco (http://produccion.chaco.gov.ar, julio de 2012) pueden leerse las declaraciones del ministro de esta cartera, Enrique Orban: "La idea es expandir el área agrícola en la provincia hasta llegar a los dos millones de hectáreas, que es una de las metas que impuso el gobernador Jorge Capitanich $y$, para esto, es necesario ir otorgando permisos de limpieza de fachinales, campos invadidos por leñosas o sistemas silvopastoriles $y$ también de monte nativo, según corresponde a la ley de Bosques de la Provincia o de la Nación, a la que nosotros estamos adheridos". (SIC)

En la propaganda radial puede escucharse reiteradamente el siguiente slogan: "Charata: ícono del despegue agrícola del Chaco". Este área se localiza en el Sudoeste chaqueño, donde en los últimos veinte años se ha perdido el $60 \%$ de las existencias forestales.

Por otro lado, el Estado o, al menos algunos de sus funcionarios, entienden que el desmantelamiento del bosque nativo es compensado con la reforestación: "...así como damos permiso para el uso de limpieza y desmonte, también vamos a ir acompañando esto con programas de forestación...de esta manera estamos reponiendo parte de los bosques que nosotros mismos estamos autorizando al uso que le corresponde por ley a cada propietario..." (Enrique Orban, 2012, Ministro de Producción y Ambiente del Chaco. SIC). Esta apreciación no es correcta, pues a partir del momento en que una tierra forestal es explotada se generan impactos ambientales, ruptura ecológica y pérdida total o parcial de la riqueza y complejidad forestal, biológica y genética. Además, la sustitución es siempre simplificadora y no regenerativa en cuanto a condiciones biogeográficas, edáficas y ecológicas, aunque se implanten especies nativas y, peor aún, cuando se trata de exóticas o introducidas de rápido crecimiento.

Publicado en formato digital: Dr. Dante Edin Cuadra. LA PROBLEMÁTICA FORESTAL EN LA PROVINCIA DEL CHACO, ARGENTINA. UN ANÁLISIS DESDE LA GEOGRAFÍA. Revista Geográfica Digital. IGUNNE. Facultad de Humanidades. UNNE. Año 9. No 18. Julio - Diciembre 2012. ISSN 1668-5180 Resistencia, Chaco. En: http://hum.unne.edu.ar/revistas/geoweb/default.htm 
En cuanto al aprovechamiento silvo-pastoril, que con entusiasmo impulsan el gobierno provincial y algunas instituciones dependientes como el INTA o el IIFA a través de diferentes planes a lo largo del tiempo, en los que participan profesionales y técnicos agrónomos y forestales, merece algunas apreciaciones desde el punto de vista geográfico: la primera de ellas es que el bosque sujeto a raleo, siembra de pasturas y, lógicamente, pastoreo, tiende a degradarse con el paso del tiempo, tanto por causas naturales como por efectos de las acciones antrópicas. Son varias las ONG que han denunciado que muchas de las autorizaciones silvo-pastoriles que se extienden en el Chaco son desmontes encubiertos. Este proceso, a veces, es premeditado y, en ocasiones, actúan causas naturales o fortuitas. En el primer caso, es recurrente que el productor sin intención de desarrollar la actividad silvo-pastoril sólo acate la primera parte de su compromiso, es decir, deja ciento veinte árboles por ha (que en la realidad suelen ser menos) y procede a plantar pasturas en ese predio; pero, al siguiente año denuncia un incendio accidental en su campo que acaba con los individuos forestales allí presentes, con lo cual -libre de responsabilidades- obtiene su doble propósito: deshacerse del monte y desplegar la actividad agrícola o ganadera sin restricciones. En el segundo caso, puede ocurrir que el fenómeno pírico no sea intencional, sino que obedezca a causas fortuitas como la caída de un rayo, el "efecto lupa" de algún vidrio existente en el lugar o a acciones con o sin premeditación de terceras personas: lanzamiento de colillas de cigarrillos, de cohetes o fogones mal apagados, por ejemplo). Pero, además, el bosque natural posee una cantidad y densidad determinada de especies distribuidas en distintos estratos, con una fauna integrada por mamíferos, aves, reptiles, insectos, desintegradores, descomponedores, excavadores y otros componentes del complejo funcionamiento de los ecosistemas. Transformar y simplificar el bosque nativo implica eliminar la autoprotección que cumple la propia masa forestal: los árboles distanciados, sobre todo en las periferias de los campos son altamente vulnerables a las tormentas de viento que, año tras año, suelen ir diezmando el número de individuos. También generan cambios en las condiciones microclimáticas de la vegetación y del suelo (temperatura y humedad), queda eliminada gran parte de la fauna, se dificulta la regeneración (por pisoteo y compactación de suelos, ramoneo de aquéllos renovales que logran sobrevivir en ese ámbito compartido y competido con animales de pezuñas y gramíneas o herbáceas implantadas). Asimismo, las modificaciones que produce la introducción de pasturas en las condiciones biológicas y edáficas originales de un ámbito boscoso es elevada.

Gran parte del oriente, centro y Sudoeste del Chaco posee, en forma fragmentada, coberturas boscosas altamente degradadas: las especies más demandadas han desaparecido, han invadido especies colonizadoras en chacras abandonadas o áreas sobrepastoreadas, experimentan ingreso y pisoteo de ganado (ganadería de monte), son recorridos frecuentemente por cazadores y recolectores de leña, por tanto, el proceso de empobrecimiento, tanto florístico como faunístico es cada vez más intenso. La fructificación y la aparición de renovales tienden a reducirse y los suelos a compactarse.

Tras el desmantelamiento del bosque se produce el proceso de sucesión ecológica con especies poco palatables y de rápida colonización y propagación, que según áreas y ambientes pueden estar representadas por aromito o churqui (Acacia caven), garabato (Acacia praecox), tala (Celtis spinosa), vinal (Prosopis ruscifolia), cactus o tunas, que cubren áreas a las que localmente se las denominan "fachinales".

Aromos en campo ganadero (izquierda). Talares y cactus en antiguas tierras de labranza (derecha). Departamento 25 de Mayo, Chaco.

Publicado en formato digital: Dr. Dante Edin Cuadra. LA PROBLEMÁTICA FORESTAL EN LA PROVINCIA DEL CHACO, ARGENTINA. UN ANÁLISIS DESDE LA GEOGRAFÍA. Revista Geográfica Digital. IGUNNE. Facultad de Humanidades. UNNE. Año 9. No 18. Julio - Diciembre 2012. ISSN 1668-5180 Resistencia, Chaco. En: http://hum.unne.edu.ar/revistas/geoweb/default.htm 


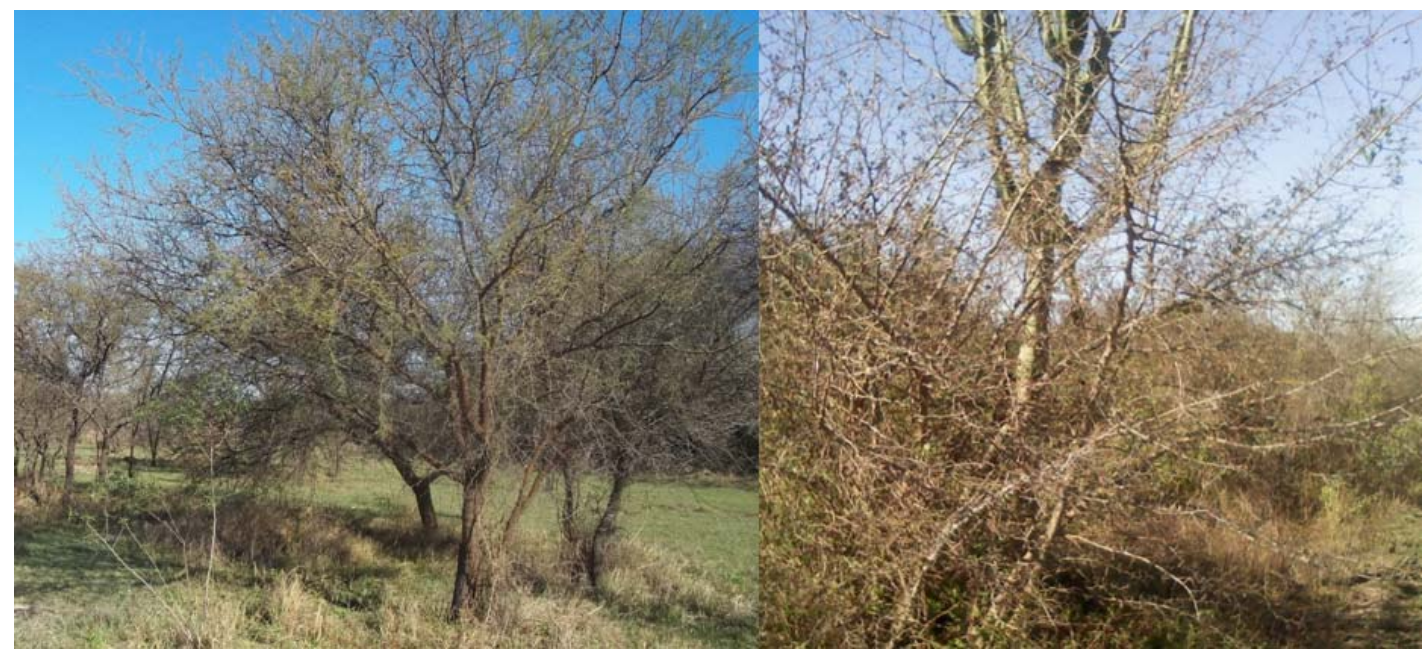

\section{Las dicotomías legales y el problema de la ilegalidad}

Aparte de la diversidad de organismos que tienen injerencia en la problemática forestal, la falta de coordinación y complementación entre varios de ellos, por pertenecer a carteras distintas dentro del Poder Ejecutivo provincial y a otras esferas del nivel administrativo nacional, también se observan dificultades vinculadas con las propias normativas legales.

Las leyes de Bosques que rigieron hasta la sanción de la nueva normativa, fueron la Ley $\mathrm{N}^{\circ}$ $2.386 / 79$ y su Modificatoria $N^{\circ} 5.285 / 03$, reglamentadas por el Decreto $N^{\circ} 1.586 / 04$. Ante los intensivos desmontes que se venían realizando en la provincia, en el año 2006, mediante Decreto № 1.341, la provincia suspendió el otorgamiento de permisos de desmontes hasta tanto finalizaba el Ordenamiento Territorial de la provincia, permaneciendo vigentes los permisos de aprovechamiento forestal, silvopastoril y deslinde predial. La provincia adhirió a la Ley nacional de Bosques $N^{\circ}$ 26.331/07, sancionando la ley № 6.409/09 de Ordenamiento Territorial de los Bosques Nativos de la Provincia del Chaco y aprobando el Decreto $\mathrm{N}^{\circ}$ 932/10, reglamentario de las mismas. La Subsecretaría de Recursos Naturales del Ministerio de Producción fue designado como autoridad de aplicación del régimen legal de los bosques y en materia del Ordenamiento Territorial de los Bosques Nativos de la Provincia del Chaco, de acuerdo con el artículo $9^{\circ}$ del Decreto Reglamentario $N^{\circ}$ 932/10 y con el artículo $2^{\circ}$ del Decreto Modificatorio $N^{\circ} 81 / 11$.

El Chaco dispone de diversas normas con distintas prerrogativas y alcances, incluso, con ciertas diferencias de criterios entre algunas de ellas. Por ejemplo, el Decreto provincial $\mathrm{N}^{\circ} 2.249$ del año 2011 se contrapone con leyes provinciales y con la propia Constitución del Chaco. El mencionado decreto faculta a ocupantes de tierras fiscales a realizar explotación forestal, violando de ese modo el artículo 29 de la Ley de Tierras № 2.913 y al artículo 42 de la carta magna de la provincia. Dispone que, para habilitar la explotación forestal de un predio, se podrá presentar un acta de ocupación otorgada por el Instituto de Colonización o también por la Policía o un Juzgado de Faltas, desautorizándose así al Instituto de Colonización, que legalmente es el único organismo con prerrogativa de extender actas de ocupación y de adjudicación. Por lo tanto, cuando la Dirección de Bosques extiende permisos de explotación forestal, tomando como válida un acta policial o de un Juzgado, no sólo estaría pasando por sobre las facultades del Instituto de Colonización, sino incumpliría con las normas legales, pues un decreto no tiene la fuerza de una ley.

Dentro de la diversidad de normas legales coexistentes en materia ambiental en la provincia del Chaco, pueden citarse las siguientes: la Ley 3.912: ratifica el Pacto Federal Ambiental firmado entre las provincias y el Gobierno Nacional para la preservación, conservación, mejoramiento y recuperación del ambiente; la Ley 3.964: aborda la preservación, conservación, defensa mejoramiento del ambiente para el logro del mantenimiento de la biodiversidad y óptima calidad de vida; la Ley № 4.076: protege específicamente el Patrimonio Natural y Cultural; la Ley 3.035: trata sobre el manejo del suelo para la conservación, restauración y mantenimiento de su capacidad productiva; las leyes 3.534 y 5.285: modificatorias de la Ley de Bosques 2.386: regulan la administración de los bosques a través de la defensa, regeneración, mejoramiento y ampliación de bosques útiles; la Ley 4.358: de áreas naturales protegidas, establece la conservación y promoción

Publicado en formato digital: Dr. Dante Edin Cuadra. LA PROBLEMÁTICA FORESTAL EN LA PROVINCIA DEL CHACO, ARGENTINA. UN ANÁLISIS DESDE LA GEOGRAFÍA. Revista Geográfica Digital. IGUNNE. Facultad de Humanidades. UNNE. Año 9. No 18. Julio - Diciembre 2012. ISSN 1668-5180 Resistencia, Chaco. En: http://hum.unne.edu.ar/revistas/geoweb/default.htm 
de los sistemas más representativos y valiosos del Patrimonio Natural Provincial; la Ley 4.306: declara de interés provincial y Monumento Natural a especies amenazadas y en peligro de extinción, con el fin de protegerlas y recuperar sus poblaciones; la Ley 5.629: sobre el control y manejo de los recursos de la fauna silvestre y la caza y, además, la Ley 5.628: sobre el manejo de los recursos acuícolas y pesca.

Contar con un gran dispositivo legal no es garantía de que los recursos naturales se hallen resguardados plenamente: la sumatoria de intereses económicos individuales, empresariales y corporativos, la tradicional deficiencia en los sistemas de controles y sanciones por parte de los organismos del Estado y la innegable existencia de una cultura inclinada a transgredir las legislaciones vigentes, repercuten en una realidad que no es exactamente la que indican los datos oficiales. Se calcula que, como mínimo, el $20 \%$ de la actividad forestal no pasa por ninguna estadística, es decir, se realiza en la clandestinidad y, por tanto, no se declara. Otras operaciones guardan una seudolegalidad: por ejemplo, los transportistas utilizan las mismas guías autorizadas para varios viajes desde el obraje hasta el destino o, la guía estipula una carga que, en la práctica, es duplicada. Lo mismo sucede con los productos elaborados, como muebles, aberturas o implementos rurales. Suponiendo que la ilegalidad fuera solamente del 20\%, ello implica un volumen de 140.000 tn de maderas que se extraen del bosque chaqueño cada año, que no aparecen en los registros oficiales.

Con respecto a la mano de obra, la actividad se caracteriza por una gran informalidad: en los aserraderos y carpinterías más del $40 \%$ de los empleados no se hallan inscriptos, siendo más elevada esta estadística en los obrajes. Muchos de ellos prefieren no estar registrados, de ese modo, continúan percibiendo beneficios a través de los planes sociales.

\section{La actividad forestal: un sistema deficiente}

Lo que a la naturaleza le ha llevado siglos o milenios construir, el hombre ha modificado o eliminado en sólo décadas. El bosque, monte o parque chaqueño tiene caracteres diferenciados en el Este (ambiente más húmedo, con más de cincuenta especies de árboles), en el centro (subhúmedo, con unas veinticinco especies arbóreas) y en el Oeste (semiárido, con alrededor de quince representantes fanerofitos). El clima subtropical del Chaco ofrece algunas peculiaridades y, una de ellas, es su variabilidad anual e interanual, tanto desde el punto de vista térmico, como pluviométrico; un ámbito que puede presentar un año o una seguidilla de ellos con gran pluviosidad o sequías extremas, lluvias anticipadas o tardías, posibilidades de granizadas y tormentas, existencia de heladas tempranas en abril o mayo, tardías en julio o agosto o, directamente, sin heladas en inviernos atemperados. Este carácter de imprevisibilidad ha constituido siempre un factor altamente negativo para el esquema agropecuario y ha sido -en gran parte- responsable de los repetidos fracasos y, por consiguiente, de la pobreza de los pequeños y medianos productores agrícolas y ganaderos del área.

Las particularidades climáticas, resultantes de la ubicación geográfica, de un relieve llano y del dominio ejercido por las masas de aire tropical y polar, posibilitaron -a través de la historia evolutiva y las cadenas de interacciones generadas en ese proceso- la formación de una vegetación, en gran parte arbórea, con caracteres xerofíticos y una rica fauna asociada, que ha sido clasificada como Provincia Chaqueña, dentro del Dominio Chaqueño y de la Región Neotropical, desde el punto de vista fitogeográfico. Se trata de un área situada a mitad de camino entre los ambientes tropicales y templados y, como espacio de transición, muestra la variabilidad aludida previamente.

Debe reconocerse que, para conformar el bosque chaqueño, la naturaleza ha sido un sistema muy eficiente y ha apelado a mecanismos de adaptación para desarrollarse en las condiciones descriptas: árboles como el quebracho colorado y el guayacán requieren un tiempo de cien años para llegar a la adultez y, el algarrobo, para un adecuado aprovechamiento debe tener entre 45 y 80 años.

Por el contrario, la explotación forestal es un sistema altamente deficiente; el máximo de deficiencia se da con la tala rasa, cuando el objeto de explotación es eliminado y no se genera reemplazo (reforestación). Según la especie, los caracteres físico-estructurales y la edad de los árboles, entre el 40 y el $60 \%$ de la materia (ramas, subramificaciones, base y raíces) no son objeto de la explotación y quedan en el monte como desperdicios que, en el mejor de los casos, puede aprovecharse para obtener leña, carbón, productos artesanales o abonos. Si la madera es transportada a una fábrica de tanino, su rendimiento será de alrededor de un $25 \%$ y nunca más del $40 \%$; lo mismo ocurre si la madera tiene por destino una fábrica de muebles, aberturas o implementos rurales. Algunos de sus desechos pueden reutilizarse en la producción de artesanías, pellets

Publicado en formato digital: Dr. Dante Edin Cuadra. LA PROBLEMÁTICA FORESTAL EN LA PROVINCIA DEL CHACO, ARGENTINA. UN ANÁLISIS DESDE LA GEOGRAFÍA. Revista Geográfica Digital. IGUNNE. Facultad de Humanidades. UNNE. Año 9. No 18. Julio - Diciembre 2012. ISSN 1668-5180 Resistencia, Chaco. En: http://hum.unne.edu.ar/revistas/geoweb/default.htm 
(biocombustibles), espirales y abonos, pero estos usos están escasamente presentes en la provincia. En el área de mayor presencia foresto-industrial (Machagai-Quitilipi-Presidencia de La Plaza), los costaneros y despuntes suelen usarse en la producción de carbón y como leña (para uso doméstico y hornos de ladrillerías y panaderías); una parte de la cascarilla es utilizada en las canchas de las ladrillerías, pero el resto y el aserrín son depositados en basurales -muchos de ellos clandestinos- o se incineran en los mismos predios de las fábricas, generando efectos nocivos para el ambiente y la salud humana, aparte de los riesgos de incendio para las propias instalaciones y los campos vecinos.

\section{Aserradero-carpintería típico de Machagai, en el centro del Chaco.}

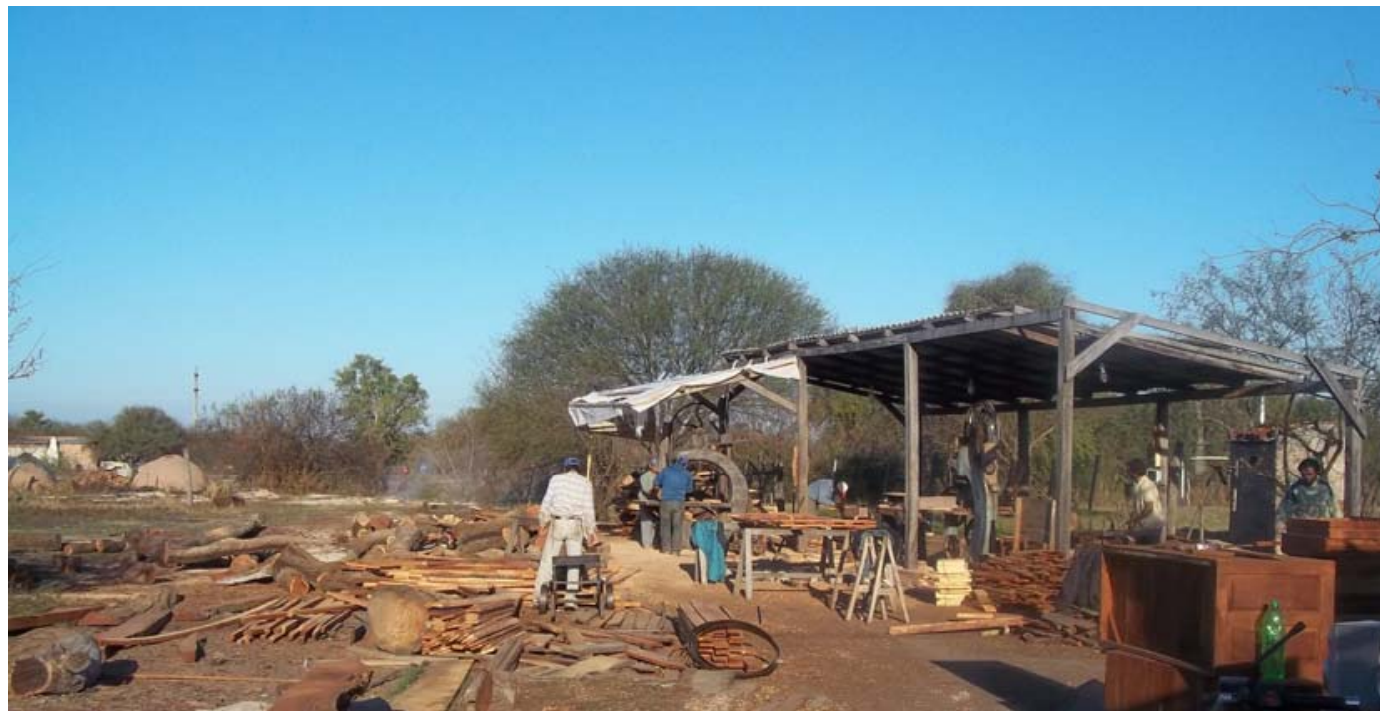

\section{Las actividades conexas}

Detrás del bosque se halla una diversidad de sujetos y sectores que obtienen beneficios directos e indirectos de su explotación, que ocupan distintos eslabones dentro del tejido social y que, en conjunto, mueven cifras millonarias en términos monetarios. Los principales demandantes son las fábricas de tanino y furfural, los aserraderos y las carpinterías. Alrededor de esta actividad hay empresarios, empleados, transportistas, instituciones, funcionarios, administrativos, bancos, sistemas financieros, cuentapropistas, intermediarios, gremios, organismos de investigación, consultoras, profesionales, comerciantes de bienes y servicios, exportadores, importadores, expendedores de combustibles, de energía eléctrica, talleres mecánicos, propietarios de montes, productores agropecuarios, pueblos originarios, peones y changarines.

Sólo por citar algunas de las entidades que convergen en esta trama, se mencionan las Asociaciones de Productores Forestales, AFIP (Administración Federal de Ingresos Públicos), municipios, INTA (Instituto Nacional de Tecnología Agropecuaria), IIFA (Instituto de Investigaciones Forestales y Agropecuarias), Direcciones de Bosques de la Nación y de la Provincia, Instituto de Colonización, cámaras de Industria y Comercio, estudios jurídicos y contables, universidades y centros de desarrollo tecnológico.

Ninguno de los sujetos y sectores que obtienen ganancias estarían dispuestos a renunciar a los beneficios generados por la actividad forestal, de modo que ejercen suficiente presión para que la explotación de los bosques no cese.

Se tomará solamente un ejemplo dentro de la complejidad del sistema forestal, como es el sector expendedor de combustibles, sin considerar el consumo de tractores, máquinas-grúas, motosierras $u$ otros vehículos utilizados en transportes cortos dentro de los campos o entre establecimientos fabriles, ni los transportes que sacan los productos fuera de la provincia. Partiendo del dato oficial de producción maderera del año 2010, de 1,2 millones de tn y asignando una media de $30 \mathrm{tn}$ por equipo de transporte para una distancia promedio de $150 \mathrm{~km}$, que entre ida y vuelta implican $300 \mathrm{~km}$, se arriba a los siguientes resultados: se necesita contar con 40.000 equipos que deben recorrer dicha distancia, lo que hace una sumatoria de 12 millones de $\mathrm{km}$ que demandan 1.200.000 litros de combustible, cuyo valor total sería de 6.600.000 pesos (casi un millón y medio de 
dólares). Este es uno de los tantos componentes conexos de la cadena forestal, por tanto, no resulta difícil imaginar la renuencia y resistencia que genera toda medida que desaliente este ritmo de explotación, más allá de que -como lo indica el sentido común- la disponibilidad del recurso continúe estrechándose, los impactos ambientales se agudicen y se comprometa el futuro de las nuevas generaciones. Esto es previsible y lógico ante las tasas de extracción existentes, a pesar de que el Estado (o sus funcionarios) no lo admitan.

\section{Consideraciones finales}

El bosque chaqueño, en sus diversos paisajes y formas, constituye la esencia de la historia social y cultural del Chaco, con innegables valores materiales y simbólicos que le han otorgado identidad como espacio geográfico.

Sus diferentes roles, según los actores y sectores que lo visualizaron, permite observar que -en el transcurso del tiempo- fue depositario de distintas percepciones y valoraciones: inicialmente como hábitat de etnias originarias, luego como obstáculo para la conquista territorial, después apreciado como recurso valioso y elemento estratégico para el dominio y apropiación del espacio y, finalmente, como variable de ajuste ante el avance de la frontera agropecuaria. Estas etapas se desarrollaron no sin conflictos. Siempre el bosque, al ser centro de diversos intereses, generó altercados de naturaleza política, social, económica y cultural, que al día de hoy no han logrado resolverse. Las interpretaciones, lecturas, discursos, medidas y acciones han transitado un delicado itinerario, en el que algunos han conseguido imponerse y otros han quedado al margen o, peor aún, han sufrido el destierro, el despojo y la violencia.

En las últimas décadas hemos asistido a una explotación intensa del bosque chaqueño, en la que no sólo han desaparecido individuos biológicos (cierto número de plantas y animales), sino que se trastocaron especies y ecosistemas enteros: algunos por explotación directa intensiva (sobreexplotación o ultraexplotación) y, otros, por factores indirectos, al perderse las condiciones ecológicas vitales como los requerimientos de luz, sombra, temperatura, humedad, composición del suelo y presencia de microorganismos; estas situaciones han roto las relaciones simbióticas de mutualismo y comensalismo, alentando el ingreso de especies invasoras o foráneas. Se observa, asimismo, que las sucesiones vegetales producidas luego de los disturbios antrópicos no evolucionan hacia condiciones primigenias.

El bosque chaqueño ha sido tradicionalmente el "recurso de los pobres", al permitirles obtener leña para vender o alimentar fogones, hornos de ladrillerías, producir carbón, artesanías y construir corrales para los animales. Pero también representa el "negocio de los ricos", un gran mercado para una compleja cadena de intereses económicos de fuerte gravitación en la provincia del Chaco y fuera de ella.

El bosque lleva siempre las de perder en su convivencia con el hombre, cualquiera sea el tipo de intervención: desmontes para actividades agropecuarias, producción de tanino, leña, carbón, utensilios diversos, postes, varillas, construcción de alcantarillas, puentes, ferrocarriles, viviendas, mobiliarios, actividades silvo-pastoriles, raleo, caza, introducción de nuevas especies o incendios. Las acciones de remediación, repoblación y mitigación en estos ambientes han sido, hasta ahora, incipientes.

El delicado equilibrio entre los roles del Estado, de las empresas agropecuarias y forestales, de los industriales, transportistas, pequeños y medianos productores, comunidades originarias y restantes componentes del sistema forestal, requiere de políticas firmes y programas claros de gobierno, que posibiliten el aprovechamiento racional de los recursos, a la vez que resguarden parte de ellos para las futuras generaciones. En tal sentido, tanto a los decisores políticos, como a las entidades civiles y a los ciudadanos en general, les cabe el deber de actuar con honestidad y sentido ético, sin pensar en favorecer meros intereses individuales o corporativos, sino apuntar al bien general o colectivo, a los fines de lograr un justo equilibrio del trípode ambiente-economía-sociedad.

\section{Fuentes y bibliografía consultadas}

Alberto, Juan A. (2006). El Chaco oriental y sus fisonomías vegetales. Revista Geográfica Digital № 5. Año 3. Enero-Junio de 2006. Instituto de Geografía - UNNE. 9 pp. Resistencia, Chaco. ISSN 16685180. En línea en: http://hum.unne.edu.ar/revistas/geoweb/homeig0.htm 
Revista Geográfica Digital. IGUNNE. Facultad de Humanidades. UNNE. Año 9. № 18. Julio - Diciembre 2012. ISSN 1668-5180 Resistencia, Chaco

Barbetta, Pablo N. y Lapegna, Pablo (2004). No hay hombres sin tierra ni tierra sin hombres: luchas campesinas, ciudadanía y globalización en Argentina y Paraguay. En Giarracca, Norma y Levy, Bettina (comp.): Ruralidades latinoamericanas. Identidades y luchas Sociales. CLACSO, Buenos Aires.

Blombäck, P. y Poschen, P. (2003). ¿Es digno el trabajo del sector forestal?. Mejora del trabajo forestal y de los medios de subsistencia que dependen de los bosques. XII ${ }^{\circ}$ Congreso Forestal Mundial. Québec, Canadá.

Borrini, Héctor (1999). Los efectos de la industria en el Territorio Nacional del Chaco (1878-1950). En: Folia Histórica del Nordeste No 14. Instituto de Historia, Facultad de Humanidades, UNNE. Instituto de Investigaciones Geohistóricas, CONICET-FUNDANORD. Resistencia Chaco. Pág. 95 a 119.

Bruniard, Enrique (1979). El Gran Chaco Argentino (ensayo de interpretación geográfica). Revista Geográfica No 4. Instituto de Geografía, Facultad de Humanidades, UNNE. Resistencia Chaco. Pág. 5 a 113.

Bünstorf, Jürgen (1982). El papel de la industria taninera y de la economía agropecuaria en la ocupación del espacio chaqueño. Folia Histórica del Nordeste № 5 . Instituto de Historia -Facultad de Humanidades - UNNE e Instituto de Investigaciones Geohistóricas - CONICET. Resistencia, Corrientes. Pp. 7 a 59.

Cabrera A. y Willink, A. (1980). Biogeografía de América Latina. OEA. Buenos Aires, Argentina.

Cabrera, Angel (1976). Regiones Fitogeográficas Argentinas. Enciclopedia Argentina de Agricultura y Jardinería. Tomo II. Editorial ACME. Buenos Aires.

Cuadra, Dante E. (2009). Actividad industrial maderera en tres ciudades vecinas del norte argentino. Vulnerabilidades sociales y ambientales. En: XII Encuentro de Geógrafos de América Latina. Universidad de la República. Montevideo, Uruguay. Abril de 2009. Resumen publicado en papel. Trabajo completo publicado en línea (15 páginas): http://egal2009.easyplanners.info/area07/7123 CUADRA Dante.doc

Cuadra, Dante E. (2011). Los recursos madereros. Condiciones socioeconómicas vinculadas con su aprovechamiento en la Provincia del Chaco. Revista Geográfica Digital № 15. Año 8. Enero-Junio de 2011. Instituto de Geografía - UNNE. 15 pp. Resistencia, Chaco. ISSN 1668-5180. En línea en: http://hum.unne.edu.ar/revistas/geoweb/homeig0.htm

Cuadra, Dante E. (2012). Industria maderera y vulnerabilidad socio ambiental. El caso de Machagai en el centro del Chaco. En: Foschiatti, Ana María (Directora y Compiladora), (2012). Escenarios vulnerables del nordeste argentino. UNNE-Agencia-CONICET. Ediciones Moglia S.R.L. Corrientes, Argentina. Pp. 313 a 336. ISBN 978-950-656-140-6.

Dirección de Bosques de la Provincia del Chaco. Secretaría de Recursos Naturales. Ministerio de la Producción y Ambiente. Estadísticas. Años 2001-2010. En: http://cedei.produccion.chaco.gov.ar/Bosques/

Dirección de Estadística y Censos de la Provincia del Chaco. Subsecretaría de Programación y Coordinación Económica. Ministerio de Economía, Obras y Servicios Públicos. El Chaco en cifras. Años 1980-2001.

Estebanez, José (1978). Tendencias y problemática actual de la Geografía. Ed. Cincel. Madrid, España.

García Pulido, José (1975). La explotación del quebracho e historia de una empresa: la tragedia de nuestros hacheros. Casa García. Resistencia.

Publicado en formato digital: Dr. Dante Edin Cuadra. LA PROBLEMÁTICA FORESTAL EN LA PROVINCIA DEL CHACO, ARGENTINA. UN ANÁLISIS DESDE LA GEOGRAFÍA. Revista Geográfica Digital. IGUNNE. Facultad de Humanidades. UNNE. Año 9. No 18. Julio - Diciembre 2012. ISSN 1668-5180 Resistencia, Chaco. En: http://hum.unne.edu.ar/revistas/geoweb/default.htm 
Revista Geográfica Digital. IGUNNE. Facultad de Humanidades. UNNE. Año 9. № 18. Julio - Diciembre 2012. ISSN 1668-5180 Resistencia, Chaco

Girbal de Blacha, Noemi M. (1993). Explotación forestal, riesgo empresario y diversificación económica: las inversiones argentinas en el Gran Chaco (1905-1930). Revista de Historia de América № 116. Instituto Panamericano de Geografía e Historia. México.

Gori, Gastón (1974). La Forestal. Buenos Aires. Editorial Proyección S.R.L. Pág. 5 a 260.

López Piacentini, Carlos P. (1979). Historia de la Provincia del Chaco. Ed. Región. Tomos I a V. Resistencia.

Madueño, R. (1948). Las industrias forestales argentinas. Universidad de Buenos Aires. Fac. de Ciencias Económicas. Instituto de la Producción. Public. № 7. Buenos Aires.

Maeder, Ernesto (1997). Historia del Chaco. Editorial Plus Ultra. Colección: Historia de nuestras provincias. Capital Federal. Pág. 153 a 295.

Manoiloff, Raúl (2001). El cultivo del algodón en el Chaco entre 1950 y nuestros días. La etapa de crisis. Meana Impresores. Resistencia Chaco. Pág. 27 a 532.

Manoiloff, Raúl (2005). la crisis del algodón en el Chaco y los cultivos alternativos. Moglia S.R.L. Corrientes. Pág. 13 a 302.

Manoiloff, Raúl (Director), (2009). Las actividades primarias. Atlas Geográfico de la Provincia del Chaco. Tomo III. Revista Geográfica No 16. Instituto de Geografía, Facultad de Humanidades, UNNE. Resistencia Chaco. Pág. 68 a 75.

Ministerio de Producción. Provincia del Chaco (2012). Declaraciones del Ministro Enrique Orban. En: http://produccion.chaco.gov.ar, julio de 2012.

Miranda, Guido (1980). Tres Ciclos Chaqueños (Crónica Histórica Regional). Nordeste Impresora. Resistencia.

Morello, Jorge (1987). Manejo integrado de recursos naturales. En Brailovsky, A.: Introducción al estudio de los recursos naturales, EUDEBA, 1987.

Morello, Jorge y Mateucci, Silvia (2007). Singularidades territoriales y problemas ambientales de un país asimétrico y terminal. CONICET. CEA-UBA. En línea: www.geocapacitacion.com.ar /biblio/tercer/adamini/singu.doc

Muscar Benasayag, Eduardo; Alfonso, Elena y Torrente, Daniela (2011). La industria maderera en la Provincia del Chaco como estímulo al desarrollo local: posibilidades y dificultades. En: Folia Histórica del Nordeste № 19. Instituto de Historia, Facultad de Humanidades, UNNE. Instituto de Investigaciones Geohistóricas, CONICET-FUNDANORD. Resistencia Chaco. Pág. 245 a 268.

Ospital, María Silvia (1990). Condiciones laborales en la explotación forestal. Gran Chaco Argentino (1890-1920). En: Folia Histórica del Nordeste No 9. Instituto de Historia, Facultad de Humanidades, UNNE. Instituto de Investigaciones Geohistóricas, CONICET-FUNDANORD. Resistencia Chaco. Pág. 5 a 23.

Pértile, Viviana y Torre Geraldi, Alejandra (2011). El oeste chaqueño. Una aproximación a la relación hombre-naturaleza. Revista Geográfica Digital. IGUNNE. Facultad de Humanidades. UNNE. Año 8. No 16. Julio - Diciembre 2011. ISSN 1668-5180 Resistencia, Chaco. En: http://hum.unne.edu.ar/revistas/geoweb/default.htm

Secretaría de Ambiente y Desarrollo Sustentable de la Nación (2007). Primer Inventario Nacional de Bosques Nativos. Informe Nacional. Proyecto Bosques Nativos y Áreas Protegidas BIRF 4085-AR 1998-2005. Buenos Aires. Pág 1 a 63. 
Secretaría de Ambiente y Desarrollo Sustentable de la Nación (2007). Primer Inventario Nacional de Bosques Nativos. Informe Regional Parque Chaqueño. Proyecto Bosques Nativos y Áreas Protegidas BIRF 4085-AR 1998-2005. Pág 1 a 87.

Seward, E. J. (1957). La industria del extracto de quebracho en la República Argentina. Universidad de Buenos Aires. Fac. de Ciencias Económicas. Instituto de la Producción. Public. № 52. Buenos Aires.

Tortorelli, Lucas (2009). Maderas y bosques argentinos. Tomo I y II. $2^{\circ}$ edición. Orientación Gráfica Editora SRL. Buenos Aires.

Tuan, Yi-Fu (2007). Topofilia. Ed. Melusina S.L. España.

Virasoro, Rafael (1971). La Forestal Argentina. Centro Editor de América Latina S.A., Buenos Aires, Argentina. 